\title{
Section 8(b)(1)(A) from Allis-Chalmers to Pattern Makers' League: A Case Study in Judicial Legislation
}

In 1947, Congress added the Taft-Hartley amendments to the National Labor Relations Act (NLRA). ${ }^{1}$ The amendments included rules governing employee-union relations. The ainendment to section $7^{2}$ and the addition of section $8(\mathrm{~b})(1)(\mathrm{A})^{3}$ largely defined the limits of a uunon's power to discipline employees in a bargaining unit.

The amended section 7 gives employees the right to refrain from union activity: "Einployees shall have the right to self-organization, to form, jon1, or assist labor organizations, .. . and shall also have the right to refrain from any or all of such activities ...."4

Section $8(b)(1)(A)$ inakes it an unfair labor practice for a umion to coerce or restrain an employee in the exercise of his section 7 rights. $^{5}$ Section $8(b)(1)(A)$ contains a proviso, however, that excepts union membership rules from the restrictions of the section. The proviso states, "[Section 8(b)(1)(A)] shall not impair the right of a labor organization to prescribe its own rules with respect to the acquisition or retention of menibership therein." 6

Section 8(b)(1)(A) and its proviso read together provide that a union nay not coerce or restram employees in their decision to engage in or refrain fron section 7 activities without committing an unfair labor practice. However, through its power to withhold inenibership or expel menibers, a union may gam coinpliance with its rules even when those rules interfere with an einployee's otherwise unbridled discretion to engage $\dot{n} 1$ or refrain from collective activity. Early cases and decisions of the National Labor Relations Board (the Board) applied these rules hterally. Since the middle 1960 's, however, the law of union discipline has not followed these contours. The Board and courts have allowed unions

1. These amendments appear in the Labor Management Relations Act of 1947 (LMRA). 29 U.S.C. $\$ \S 1-197$ (1982). The amendments were passed after extensive and heated debate. See Senate Comm. on Labor and Public Welfare, 93D CONG., 2D SEss., Legislative History OF THE LABOR MANAGEMENT RELATIONS ACT, 1947 (1974) [hereinafter HistoRy].

2. 29 U.S.C. $\S 157$.

3. 29 U.S.C. $\S 158(\mathrm{~b})(1)(\mathrm{A})$.

4. 29 U.S.C. $\$ 157$ (emphasis added).

5. Section 8(b)(1)(A) states, "It shall be an unfair labor practice for a labor organization or its agents ... to restrain or coerce . . employees in the exercise of the rights guaranteed in [\$ 7]." 29 U.S.C. $\S 158(\mathrm{~b})(1)(\mathrm{A})$.

6. Id. 
to use judicially enforceable fines to enforce union rules affecting the freedoin of employees to engage in or refrain from collective activity. During the same period, the Board and the courts also have construed section $8(\mathrm{~b})(1)(A)$, despite its proviso, to restrict a union's freedom to determine its inembership rules.

The case law that has developed around section 7 and section $8(b)(1)(A)$ has focused on two issues. First, what are the limits to a union's power to expel members? Second, under what circumstances may a union use the courts to enforce fines for violations of membership rules? This Comment argues that the case law concerning expulsion and union discipline has developed unpredictably and has made an unnecessary, unjustified, and harmful move away from a literal application of the statutes.

Part I will show that both the legislative history and the plain words of the ainendments indicate that Congress intended to insulate employees' jobs from retribution resulting from their organizational activity or inactivity and to create thereby a zone of employee free action. The language and legislative history also indicate, however, that the creation of this employee autonomy was not meant to impair a union's power to enforce its membership decisions. Early case law and Board decisions evince a corresponding concern for the autonoiny of both einployees and umions through hiteral application of the statute. Part II will trace what the Court and the Board have in fact done. I will illustrate how the courts and the Board have developed an open-ended, "common law"7 approach to union discipline and membership rules. In Part III, I will argue that such a common law approacli substitutes an unnecessarily complicated and unpredictable scheme for the clear and workable system created by Congress. The current regime also erodes unions' ability to apply economic pressure effectively and to maintain internal discipline. Part IV will reconstruct the original regulatory inodel designed by Congress. Congress envisioned a reasonable and self-administering scheme of employee-union relations. This sclieme would effectively protect both employee autonomy and the institutional interests of unions.

I

Language, Legislative History, and Early Cases

Sections 7 and $8(b)(1)(A)$ prescribe a clear, workable scheme for employee-union relations. Such a sclieme is clearly articulated by the

7. Professor Gorman has observed that "the Board and courts have dramatically departed from the literal text of section $8(\mathrm{~b})(1)(\mathrm{A})$ and have created what might be called a 'common law' of union discipline." R. Gorman, Basic TeXt on LABOR LAW-Unionization \& Collective BARGAINING 677-78 (1976). 
statutes, is supported by the legislative history of the two amendments, ${ }^{8}$ and is evident in the hteral ${ }^{9}$ apphication of the statutes by the Board and the courts in their early decisions.

In the Taft-Hartley amendments, Congress sought to circumscribe union power because of a perceived imbalance between the powers of umion and employer. ${ }^{10}$ Section 7 , as amended and implemented by section $8(\mathrm{~b})(1)(\mathrm{A})$, creates a zone of employee action free from interference by either employer or umion. ${ }^{11}$ Just as the original NLRA gave employees the right to engage in certain activities free froin the fear of employer

8. I do not dispute that legislative history or framers' intent is inescapably ambiguous. Admittedly, it is always possible to construe framers' purposes more or less broadly. I do contend, however, that when legislation creates a zone frce of judicial interference explicitiy intended to give free play to economic forces and individual choices without judicial interference within that zone, the standard arguments as to the permissible scope of judicial iuterpretation are largely irrelevant. The Act's structure dictates no particular pattern of outcomes or results. Instead, it creates a framework of regulation within which employees and unions may settle their disputes. Accordingly, attempts to justify judicial concern with the equities of particular instances of union discipline or employee disobedience to union rules is misplaced. $C f$. R. NOZICK, ANARCHY, STATE, AND UTOPIA 149-55 (1974) (distinguishing patterned principles of justice from historical principles of justice, that is, distinguishing rules governing outcomes from rules govening process).

A number of writers have asserted that the legislative history of $\$ \$ 7$ and $8(\mathrm{~b})(1)(\mathrm{A})$ does not provide adequate grounds for a definitive interpretation. See, e.g., Cox, Some Aspects of the Labor Management Relations Act, 1947, 61 HARV. L. REV. 1, 33 (1947) ("Section 8(b)(1) may plunge the Board into a dismal swamp of uncertainty. . . . A long period of uncertainty and heavy volume of litigation will be necessary before the questions of interpretation can be resolved."). Many commentators have echoed Cox's point. Archer, Allis-Chalmers Recycled: A Current View of a Union's Right to Fine Employees for Crossing a Picket Line, 7 IND. L. REv. 498, 498 n.5 (1974) (quoting Cox); Gould, Some Limitations Upon Union Discipline Under the National Labor Relations Act: The Radiations of Allis-Chalmers, 1970 DukE L.J. 1067, 1070 (same); Harrison, Union Discipline and the Employer-Employee Relationship, 22 LAB. L.J. 216, 217 (1971) (quoting Cox and noting that "selective reliance ou the legislative history" has resulted in discrepant rulings); Silard, Labor Board Regulations of Union Discipline After Allis-Chalmers, Marine-Workers and Scofield, 38 GEO. WASH. L. REv. 187, 187 (1969) (quoting Cox and suggesting that "changing national sentiments" have encouraged "an attempted reconstruction of the legislative aim"); Note, The Right of Unions to Fine Members Who Have Engaged in Strikebreaking Activities After Resigning from the Union During a Strike, 72 Colum. L. REv. 1272, 1272 (1972) (quoting Cox). Nevertheless, examination of the language of the statutes, the legislative history, and the early rulings indicates that Congress did not intend to "put the Labor Board in the business of policing union membership regulation or discipline." Silard, supra, at 188.

9. In this Comment, I argue for a self-regulating regime of employee-union relations. I call this regime a "literal" approach. By using that term in contrast to the "common law" approach of the courts and the Board, I do not mean that the courts and the Board have wholly ignored the language of the statutes. Rather, the courts and the Board have been too quick to look beyond the words of the statute and too ready to fashion rules based upon posited Congressional intent.

10. For Congressman Hartley's explanation of why the Taft-Hartley amendments were needed, see H.R. REP. NoS. 3-6, 80th Cong., 1st Sess. 27 (1947), reprinted in HisToRY, supra note 1, at 294-97, and the corresponding comments of Senator Taft, S. REP. No. 105, 80th Cong., 1st Sess. 1-3 (1947), reprinted in HisToRY, supra note 1, at 407-09.

11. This interpretation of congressional intent finds support in the statements of several legislators. According to four Senators, iucluding Senator Taft:

It is now an unfair labor practice for employers to so interfere with, restrain, or coerce [employees]. Since this bill establishes the principle of unfair labor practices on the part of unions, we ean see no reason whatever why they should not be subject to the same rules as 
retaliation, ${ }^{12}$ the LMRA aimed to give employees the right to refrain from those activities free from the fear of union retaliation. ${ }^{13}$ In discuss-

the employers. ... We believe that the freedom of the individual workman should be protected from duress by the union as well as from duress by the employer.

S. REP. No. 105, 80th Cong., 1st Sess. 50 (1947) (supplemental views of Senators Taft, Ball, Donnell, and Jenner), reprinted in HisToRY, supra note 1 , at 456.

Senator Ball expanded on this theme in debate:

The purpose of the amendment [to $\S 7$ ] is simply to provide that where unions, in their organizational campaigns, indulge in practices which, if an employer indulged in them, would be unfair labor practices, sueh as making threats or false promises or false statements, the unions also shall be guilty of unfair labor practices.

93 CONG. REC. 4016 (1947), reprinted in HISTORY, supra note 1, at 1018.

Finally, Representative McConnell put forth the following justification for the bill: "This bill seeks to protect the freedom of the individual worker. It attempts to emancipate him from abuses of power by either a labor organization or an employer." 93 CoNG. Rec. 3440 (1947), reprinted in HisTORY, supra note 1 , at 640 .

An early Supreme Court decision, Radio Officers' Union v. NLRB, 347 U.S. 17 (1954), adopted this reading of Congressional intent. The Court noted that insulation of an employee's job from his union activity was a prominent purpose of the LMRA. Id. at 40.

Additional evidence of Congressional intent to protect an employee's job from retribution for his union activity or inactivity is found in LMRA § 8(a)(3), 29 U.S.C. $§ 158(a)(3)$ (1982). That section outlaws the closed shop, so that it is no longer possible for a union to threaten a prospective employee's job by withholding membership.

12. Under the original NLRA and corresponding provisions of the LMRA, the courts have determined that an employer commits an unfair labor practice if it attempts to discourage unionism among employees by treating umion members differently from other employees. See, e.g., NLRB v. Erie Resistor Corp., 373 U.S. 221 (1963) (unfair labor practice to offer super-seniority to strike breakers); NLRB v. Mackay Radio \& Tel. Co., 304 U.S. 333 (1938) (employer violates § 8(a)(3) by discriminating on the basis of umon activity or leadership in deciding which striking employees to reinstate); see also Republic Aviation Corp. v. NLRB, 324 U.S. 793 (1945); Edward G. Budd Mfg. Co. v. NLRB, 138 F.2d 86 (3d Cir. 1943) (unfair labor practice to discharge an employee on the basis of union activity), cert. denied, 321 U.S. 778 (1944).

Sunilarly, the courts have found that an employer commits an unfair labor practice by treating its whole work force differently than if it were nonunion. See, e.g., Textile Workers Union v. Darlington Mfg. Co., 380 U.S. 263 (1965) (employer violates $§ 8(a)(3)$ by partial plant closing, if closing is motivated by purpose of chilling unionism at employer's remaining plants and einployer has reason to foresee that effect); see also Local 57, Int'1 Ladies' Garment Workers' Union v. NLRB, 374 F.2d 295 (D.C. Cir), cert. denied, 387 U.S. 942 (1967); George Lithograph Co., 204 N.L.R.B. 431 (1973).

Furthermore, an einployer is restricted in the measures it may use when employees engage in conduct covered by $\S 7$. The employer cannot refuse to reinstatc employees who strike to protest unfair labor practices if their strike is lawful and the ennployces inake unconditional applications for reinstatement. Mastro Plastics Corp. v. NLRB, 350 U.S. 270 (1956).

Moreover, in order to proteet employee $\$ 7$ rights, an employer unust give preferential rehire status to economic strikers. An employer can hire permanent replacements for economic strikers, but if the strikers seek to return, the employer must give them priority in hiring whenever jobs open up. This preference lasts as long as the employees have not obtained substantially equivalent employment elsewhere. Laidlaw Corp., 171 N.L.R.B. 1366 (1968), enforced, 414 F.2d 99 (7th Cir. 1969), cert. denied, 397 U.S. 920 (1970).

Finally, an employer cannot threaten union or nonunion employees with loss of their jobs for engaging in activities protected by $\S 7$. For example, an employer counmitted a $\S 8(a)(1)$ unfair labor practice by discharging unorganized employees who walked off their jobs to protest cold temperatures in the workplace. NLRB v. Washington Aluminum Co., 370 U.S. 9 (1962).

13. A House report describing the amendment to $\S 7$ stated:

[It] assures that when the law states that employees are to have the rights guaranteed in 
ing the effect of the amendment to section 7, Senator Taft stated, "the amendment is founded on what I consider to be the basic theory of the entire bill, that is, an attempt to create equality between the employer and the employee [organization]." 14

The relevant words of section 7 are unambiguous. An employee shall "have the right to refrain from any or all [orgamizing] activities except to the extent that such right may be affected by an agreement requiring membership in a labor organzation as a condition of einployment as authorized in [section 8(a)(3)] . ..."15 As Senator Taft stated, the amendinent to section 7 "outlaw[s] such restraint and coercion as would prevent people from going to work if they wished to go to work." 16

A logical corollary to the right granted employees under section 7 to refrain from any or all collective activities is that a union may not seek judicial enforceinent of sanctions agamst employees who refuse to engage in those activities. This does not necessarily mean that urnons themselves may not take actions agamst employees who refuse to engage in union activity, but rather that section 7 does not permit judicial assistance of urion measures aimed at coinpelling employees to engage in urion activity.

Altlougli section 7 was intended to protect an employee's job from his organizational activity or mactivity, Congress also recognized that unions must be free to manage their imternal affairs im order to function as effective economic units. Umion autonomy over internal affairs was guaranteed despite its potential use to influence employee conduct. Thus, while section $8(\mathrm{~b})(1)(\mathrm{A})$ provides the means to enforce section 7 ,

section 7, the Board will be prevented from compelling employees to exercise such rights against their will, as it has consistently done in the past. In other words, when Congress grants to employees the right to engage in specified activities, it also means to grant them the right to refrain from engaging therein if they do not wish to do so.

H.R. REP. No. 245, 80th Cong., 1st Sess. 27 (1947), reprinted in HISTORY, supra note 1, at 318.

14. 93 CoNG. REC. 4562 (1947), reprinted in HISTORY, supra note 1, at 1206. Elsewhere Taft stated:

The present law expressly provides, and has provided for many years, that it is an unfair labor practice for any employer to interfere with, restrain, or coerce employees in the exercise of the rights guarantecd in section 7. This amendment proposes to say it shall also be an unfair labor practice for an employee organization, a union or its agents, to interfere with, restrain, or coerce employees in the exercise of the rights guaranteed in section 7.

Id. at 4021, reprinted in HISTORY, supra note 1, at 1025. Similarly, Senator Smith stated, "We are simply saying that we think that it is equally as wrong for a labor organization or its agents to restrain or coerce employees in their relationship as it is for an employer to do so." Id. at 4435, reprinted in HISTORY, supra note 1, at 1204.

15. 29 U.S.C. $\$ 157$ (1982). Section 8(a)(3) provides that employees in an "agency shop" may be required to pay union dues and fees as a condition of employment, unless state law provides otherwise. 29 U.S.C. $\$ 158$ (a)(3) (1982). However, even in an agency shop (in a state with no rightto-work law), an employec may limit his participation in union affairs to the payment of fees and dues.

16. 93 CONG. REC. 4436 (1947), reprinted in HISTORY, supra note 1, at 1207. 
the proviso to section $8(\mathrm{~b})(1)(\mathrm{A})$ specifically excepts unions from unfair labor practice liability when the means of union restraint or coercion involve the acquisition or retention of union membership. The words of the proviso are unambiguous: "[Section $8(\mathrm{~b})(1)(\mathrm{A})]$ shall not impair the right of a labor orgamization to prescribe its own rules with respect to the acquisition or retention of membership therein." 17 The proviso to section $8(b)(1)(A)$ does not conflict with the rest of the section, or with section 7. It simply permits a union to exact comphiance with its demands througli its power to withhold membership.

The legislative history of the proviso supports a literal interpretation. The Senate Report stated, "The committee did not desire to limit the labor organization with respect to either its selection of membership or expulsion therefrom."18 Senator Taft, addressing concerns that unions would be unable to protect themselves fronı malcontents under the new act, said, "The pending neasure does not propose any limitation with respect to the internal affairs of umions. They still will be able to fire any inenibers they wish to fire ...."19

17. 29 U.S.C. $\S 158(\mathrm{~b})(1)(\mathrm{A})$.

18. S. REP. No. 105, 80th Cong., 1st Sess. 20 (1947), reprinted in HisToRY, supra note 1, at 426.

19. 93 CONG. REC. 4318 (1947), reprinted in HistoRY, supra note 1, at 1097. Although Taft's language is ambiguous and may seem to suggest that unions could affect an employee's employment under the proviso, the context of his remarks makes it clear that he did not mean a union permissibly could cause an employee to lose his job because he violated a union rule. When Taft said "fire" he meant expel from union membership, not from the job. Taft made his meaning clear by stating, "If they fire a member for some reason other than nonpayment of dues they cannot make his employer discharge him from his job and throw him out of work." Id. at 4193, reprinted in HisTORY, supra note 1, at 1097.

For another instance in the legislative history underscoring that the proviso was designed to leave union membership rules to the union's discretion, see the comments of Senator Holland:

[T] he pending amendment would have no application to or effect upon the right of a labor organization to prescribe its own rules of membership either with respect to beginning or terminating membership. I understand that the amendment so offered meets with no serious objections on the part of the sponsors ....

Id. at 4272, reprinted in History, supra note 1, at 1141. See also the comments of Taft:

The union could refuse the man admission to the union, or expel him from the union; but if he were willing to enter the union and pay the same dues as other members of the union, he could not be fired from his job because the union refused to take him.

Id., reprinted in HisToRY, supra note 1, at 1142. See also the comments of Senator Pepper:

Am I correct in assuming ... there is no provision of the bill which denies a labor union the right to prescribe the qualifications of its members, and that if the union wishes to discriminate in respect to membership, there is no provision in the bill which denies it the privilege of doing so?

Id., reprinted in HISTORY, supra note 1, at 1142. Senator Ball replied to Senator Pepper, "It can expel him from the union at any time it wishes to do so, and for any reason." Id., reprinted in HISTORY, supra note 1 , at 1142.

Senator Smith stated, "It does not compel the union to admit anyone to membership or to exclude anyone from membership. It simply provides that the union may not exclude an employee from membership and then demand his discharge from his job." Id. at A2955, reprinted in HisTORY, supra note 1, at 906. 
Thus, the legislative history shows a clear intention to leave unions free to determine the terms on which an employee can acquire and maintain membership. While the amendments protect employees from coercion compelling participation in collective activity, ${ }^{20}$ under section 8 (b)(1)(A) a union is free nevertheless to demand any sort of participation in collective activity it wisles of its members. However, these demands are ultimately enforceable only by the union's power to withhold membership. While a disobedient union member may lose his membership and corresponding perquisites by disobeying a umion rule, he will keep his job and will not suffer job-related sanctions.

Until the early 1960's, the cases imterpreting the LMRA adhered to the scheme of einployee-union relations outlined above. The courts and the Board insulated employee job rights from participation or nonparticipation in collective activities while permitting unions to freely determine their internal rules, including the conditions of membership. The early understanding was that sections 7 and $8(\mathrm{~b})(1)(\mathrm{A})$ were to be applied literally.

Capital Service, Inc. v. $N L R B^{21}$ illustrates the early judicial recognition that Congress intended to create a zone of einployee freedom of action. In that case, a umion used a secondary boycott, hoping to influence employees to join the union. The Nintl Circuit held that this was economic coercion, threatening the enployee's freedom to refrain from joining the union, and found a section $8(\mathrm{~b})(1)(\mathrm{A})$ unfair labor practice. ${ }^{22}$ The court reasoned that the words "restram or coerce" in section $8(b)(1)(A)$ applied to unions in the same way they applied to employers in section 8(a)(1). ${ }^{23}$ It stated, "what was sauce for the goose under the Wagner Act is now sauce for the gander under the Taft-Hartley Act."24

In Radio Officers' Union v. $N L R B,{ }^{25}$ the Supreme Court endorsed the principle that an employee should not lose lier job because of her activity in the umion. The Court lield that a union committed botll section $8(\mathrm{~b})(1)(\mathrm{A})$ and section $8(\mathrm{~b})(2)^{26}$ unfair labor practices when it

20. Section 8(b)(1)(A) does not by its terms purport to restrict union discipline of members for misconduct unrelated to participation or support of concerted activity. Consequently, it may be permissible for unions, under unpreempted external law relating to voluntary associations, to seek court enforcement of union fines for misconduct that does not relate to the employment relation or the purposes of collective activity. It should be noted, however, that prior to the Supreme Court's decision in NLRB v. Allis-Chalmers Mfg. Co., 388 U.S. 175 (1967), unions seldom resorted to legal process in disciplining their members. See infra note 71 and accompanying text.

21. 204 F.2d 848 (9th Cir. 1953), aff d, 347 U.S. 501 (1954).

22. Id. at 853 .

23. Id. at 852 .

24. Id. at 853 .

25. 347 U.S. 17 (1954).

26. Section $8(\mathrm{~b})(2)$ provides:

It shall be an unfair labor practice for a labor organization or its agents . . . to cause or attempt to cause an employer to discriminate against an employee in violation of 
caused an employer to discriminate against an employee in order to encourage adherence to union rules. ${ }^{27}$ The Court observed, "The policy of the Act is to insulate employees' jobs from their organizational rights. Thus [sections] 8(a)(3) and 8(b)(2) were designed to allow employees to freely exercise their right to join unions, be good, bad, or indifferent members, or abstam from joining any umon without imperiling their livelihood."28 The Court drew this policy of job protection from section 7. Other early cases reiterated the policy of insulating employees' jobs from their union activities. ${ }^{29}$

The Board held that a umion could expel a member for any reason in International Typographical Union, ${ }^{30}$ one of the first cases after the passage of the LMRA. A urion had threatened a local with expulsion if it failed to comply with an edict that required the local to violate its statutory obligations by pressuring the employer to hire only union foremen. ${ }^{31}$ The Board absolved the union of any section $8(\mathrm{~b})(1)(\mathrm{A})$ liability. It stated, "[B]y mcluding this proviso Congress unmistakably intended to, and did, renove the application of a union's membership rules to its members from the proscriptions of Section 8(b)(1)(A), irrespective of any ulterior reasons motivatimg the union's apphication of such rules or the direct effect thereof on particular eniployees."32 Other early cases followed the International Typographical Union Board's lead in allowing a union the freedom to expel nembers for disobedience even when the

subsection (a)(3) of this section or to discriminate against an employee with respect to whom membership in such organization has been denied or terminated on some ground other than his failure to tender the periodic dues and the initiation fees uniformly required as a condition of acquiring or retaining membership.

29 U.S.C. $\$ 158(b)(2)(1982)$. The Radio Officers' Court found a $\$ 8(b)(2)$ violation when the union caused the employer to discriminate against an employee to encourage union membership. 347 U.S. at 52-55.

27. Radio Officers' Union, 347 U.S. at 39-40. The Court also found that the union had violated $\S 8(b)(2)$ by persuadimg the employer to discriminate against an employee who was late in paying union dues. The Court's finding focused on the fact that no effective union security agreement was in place. Id. at 42. A union bargains for a security agreement as part of its collective bargaining agreement with an employer. Such an agreement provides that an employer will fine an employee who does not pay union dues.

28. Id. at 40 (emphasis added) (footnote omitted).

29. For example, in NLRB v. Reed, 206 F.2d 184 (9th Cir. 1953), the Ninth Circuit held that a union committed unfair labor practices under $\$ \S 8(\mathrm{~b})(1)(\mathrm{A})$ and $8(\mathrm{~b})(2)$ by causing an employer to discharge employees who had violated union rules. Id. at 189. In Reed, a union member went to work for an employer without getting clearanee from his union. The union applied pressure on the employer, causing it to discharge the employee. In enforcing the Board's order finding an unfair labor practice the court stated, "to the extent that [the employec] disobeyed the Union's rules, he was refraining from assisting a labor organization. His right to so conduct himself without fear of losing his job is guaranteed by section 7." Id. (footnote omitted).

30. 86 N.L.R.B. 951 (1949), modified, American Newpaper Publishers Ass'n v. NLRB, 190 F.2d 45 (7th Cir.), enforced, NLRB v. International Typographical Union, 193 F.2d 782 (7th Cir. 1951), cert. denied, 344 U.S. 816 (1952).

31. Id. at 955.

32. Id. at 957 (emphasis added). 
union's conduct violated an important labor law policy. ${ }^{33}$

That there are not more early cases along the lines of $I T U$ suggests a settled understanding that a union could expel members for any reason. Under federal labor law, an unfair labor practices charge will not be adjudicated by a trial examiner, the Board, or a federal court of appeals unless the Board's General Counsel issues a complaint. ${ }^{34}$ Consequently, if the General Counsel refuses to issue complaints because he considers it clear that the union's conduct does not constitute an unfair labor practice, few if any cases concerning that type of union conduct will ever reacli the Board or courts. Such tacit acknowledgement that the proviso to section $8(\mathrm{~b})(1)(\mathrm{A})$ gave unions absolute autlority to expel menibers is suggested by a 1954 Administrative Ruling in which the General Counsel affirmed a regional director's refusal to issue a section $8(\mathrm{~b})(1)(\mathrm{A})$ coniplaint.

A union made an agreement witl an employer that resulted in bunping some enployees into undesirable job positions. Several of the affected eniployees filed unfair labor practice charges against the union as

33. In International Bd. of Teamsters, Local 87 (Di Giorgio Wine Co.), 87 N.L.R.B. 720 (1949), the Board held that a union was free to disciphine and even expel a meinber who disobeyed a union rule by crossing the union's picket line, even though the line itself violated $\S 8(\mathrm{~b})(4)$. Id. at 744,750 . In other cases, the Board permitted unions to use discipline enforceable by expulsion when a member failed to comply with the urion's demands that he violate an existing collective bargaining agreement. See, e.g., Perry Norvell Co., 80 N.L.R.B. 225, 240 (1948) (union may discipline members who refused to join in a strike in violation of the collective bargaining agreement). The Perry Norvell Board also noted that the legislative history of the LMRA shows that Congress specifically considered and then rejected making it an unfair labor practice for a union or an employer to violate a collective bargaining agreement. Id. (citing H.R. REP. No. 510, 80th Cong., 1st Sess., 41-42 (1947)); see also Marlin Rockwell Corp., 114 N.L.R.B. 553 (1955):

As we read the $\S 8(\mathrm{~b})(1)(\mathrm{A})$ proviso, its sole purport is to guarantee to unions the privilege, as a voluntary association, to determine both who shall be a union "meniber," and what substantive conditions a "inenber" nuust coinply with in order to acquire or retain union meinbership status. It is for this reason that the Board cannot and will not judge the fairness or unfairness of internal union determinations which nuay enable or disable particular individuals to obtain the incidental benefits of union nenibership as provided by internal union legislation.

Id. at 561-62 (footnote omitted). Similar language in analogous statutes has been construed literally. Federal courts, under the Railway Labor Act (RLA), 45 U.S.C. $\$ \S 151-188$ (1982), interpreted language like that in the proviso to $\S 8(\mathrm{~b})(1)(\mathrm{A})$ in a literal manner, permitting railroad unions to set their membership rules as they saw fit. In Oliphant v. Brotherhood of Locomotive Firemen, $156 \mathrm{~F}$. Supp. 89, cert. denied, 355 U.S. 893 (1957), aff'd, 262 F.2d 359 (6th Cir. 1958), cert. denied, 359 U.S. 935 (1959), a district court held that under the RLA, a union was not prohibited from discrininating in its nembership rules. The case was decided prior to the Civil Rights Act of 1964, and it was therefore necessary for the victim of union discrimination to show either that labor law required nondiscriminatory unions or that there was sufficient state action to invoke constitutional due process standards. Finding no state action, the court addressed the role of the judiciary in interpreting statutory regulation of union membership: "To compel by judicial mandate menibership in voluntary organizations where the Congress has knowingly and expressly permitted the bargaining agent to prescribe its own qualifications for nembership would be usurping the legislative function." Oliphant, 156 F. Supp. at 93.

34. See A. Cox \& D. BoK, Cases and Materials on Labor Law 136-38 (7th ed. 1969). 
well as against the employer. The union then threatened to suspend, and later did suspend, the employees involved because they would not withdraw the charges. An employee filed a second charge for the threatened suspensions. The regional director refused to issue a complaint. The General Counsel agreed, holding that suspension of the members and, a fortiori, threats of suspension were not unfair labor practices. The General Counsel stated, "[The] Act permits [a] union to take any action it desires respectimg acquisition or retention of membership." 35

The Board imphicitly recognized in its early cases that extension of sections 7 and $8(\mathrm{~b})(\mathrm{l})(\mathrm{A})$ beyond their hteral meaning could alter the balance of the umion-employer relationship in a manner not contemplated by Congress. For instance, in Perry Norvell Co., ${ }^{36}$ the Board observed that the legislative history of the Act indicated that section $8(\mathrm{~b})(1)(\mathrm{A})$ was directed not at the ends sought by a union, but rather at a umion's use of coercive means that affect an employee's job. ${ }^{37}$ The Board recognized that it is improper to detach policies furthered by the 1947 amendments from the specific remedies Congress provided for their vindication. A nonliteral construction of section $8(\mathrm{~b})(1)(\mathrm{A})$ threatened to redistribute the economic and bargaining tools that preserve the statute's balance of competimg policy values: preserving the strength of the bargaining unit on the one hand and fostering employee autonomy on the other.

The cases discussed above deinonstrate the recognition in early case law that use of section 8(b)(1)(A) as a free-floating mechanism to enforce other pohicy concerns reflected in the Act is inappropriate. If a union is

35. Case No. 1059, Admin. Rulings of the NLRB Gen. Counsel, 35 L.R.R.M. (BNA) 1167 (Nov. 19, 1954) (emphasis added).

36. 80 N.L.R.B. 225 (1949).

37. Id. at 239. The Board also observed that the legislative history of the Act plainly showed that $\S 8(\mathrm{~b})(1)(\mathrm{A})$ was not intended to make strikes in violation of a collective bargaining agreement unfair labor practices. The Board noted that a provision making breach of a collective bargaining agreement an unfair labor practice was proposed in an early version of the bill, but later removed. Id. at 240 \& n.29 (citing H.R. ReP. No. 510, 80th Cong., 1st Sess. 41-42 (1947)); see also National Maritime Union, 78 N.L.R.B. 971 (1948), enforced, 175 F.2d 686 (2d Cir. 1949), cert. denied, 338 U.S. 954 (1950). In that case the Board held that a union's insistence on a hiring hall clause in violation of $\S 8(\mathrm{~b})(3)$ and $\S 8(\mathrm{~b})(2)$ was not a $\S 8(\mathrm{~b})(1)(\mathrm{A})$ unfair labor practice. The Board stated:

The touchstone of a strike which is violative of Section $8(\mathrm{~b})(1)(\mathrm{A})$ is normally the means by

which it is accomplished, so long as its objective is directly related to the interests of the strikers, and not directed primarily at compelling other employees to forego the rights which Section 7 protects.

Id. at 986 . The focus of these early cases on the means of union coercion, rather than the ends served, seems directly opposed to the Supreme Court majority's reasoning 20 years later in NLRB v. Allis-Chalmers Mfg. Co., 388 U.S. 175 (1967). See infra text accompanying notes 45-74. There, the Court found court-enforced fines to be mere means to the legitimate end of internal discipline and hence not prohibited by $\S 8($ b)(1)(A). 388 U.S. at 177-78; see infra note 55 and accompanying text. It is doubtful that a court of relatively broader jurisdiction, twenty years after the passage of an act, is in a better position to discern the purposes behind a technical statutory provision than a specialized administrative tribunal in the year immediately following the passage of the act. 
able to cause its members to violate a collective bargaining agreement, respect an illegal secondary picket line, or respect the illegal picket line of another umion, an employer has other means of responding to the infractions. The employer can discipline employees who violate the collective bargaining agreement, and the Board can sanction union activity that otherwise constitutes an unfair labor practice. It is unnecessary to use section $8(\mathrm{~b})(1)(\mathrm{A})$ as a free-floating sanction to ensure the orderly working of the Act.

This Part has shown that the legislative history of sections 7 and 8(b)(1)(A) manifests an intent that they be apphied literally. A fundamental policy of the LMRA was to insulate an employee's organizational activity or inactivity from restraint or coercion by umions, just as the Wagner Act protected employees from restraint, coercion, or interference by einployers when the employees engaged in collective activity. At the saine time, by giving unions a free hand to set the terms for the acquisition and retention of membership, the LMRA shows a clear purpose to leave a umion's internal affairs free from the restrictions of section $8(\mathrm{~b})(1)(\mathrm{A})$. The legislative history and the early cases took this power of unions to be absolutely unqualified.

II

The Departure From the Literal APPROACH

Courts and the Board have subsequently rejected the literal interpretation of section $8(\mathrm{~b})(1)(\mathrm{A})$ and its proviso and, by implication, Congress's priniary policy-making role in labor law. The courts have ntanipulated the application of section $8(\mathrm{~b})(1)(\mathrm{A})$ and its proviso to address the perceived equities of particular situations, rather than to preserve and proinote the scheine of labor relations established by Congress in 1947. This Part will explore this move by the courts and the Board away front the hiteral application of the statutes.

\section{A. The Board Cases}

During the early 1960's, the Board took the lead in ignoring the express language of sections 7 and 8(b)(1)(A), and the Supreme Court soon followed suit. The new case law created vaguely defined exceptions to the limitations earlier cases had placed on a union's power to discipline its meinbers by measures otlier than expulsion. These cases also set linits on a union's freedom to set its membership rules. Contrary to legislative intent, these cases allowed unions in soine circuinstances to use court-enforced fines to discipline dissident inentbers, and held that a union could no longer freely expel ineinbers for any reason it might choose.

The policies guiding the Court and tlie Board were protection of 
unions as bargaining representatives on the one hand and protection of employee freedom from union disciplimary power on the other. However, rather than acceptimg the statutory scheme that implicitly balanced these interests, the courts and the Board have resorted to open-ended policy analysis. In devising rules, exceptions to the rules, and exceptions to the exceptions to the rules, they have created common law doctrine susceptible to the exercise of ideological and philosophical biases. The new method of analysis applied by the courts and the Board has facilitated justification of significant changes in the law of umion discipline and has allowed uncertainty to envelop the doctrine.

The Board first endorsed court-enforced fines as a means of disciplining dissident members in Local 283, United Automobile, Aircraft \& Agricultural Implement Workers (Wisconsin Motor Corp.) ${ }^{38}$ In that case, a union fined but did not expel members who had violated a union rule barring them from receiving additional pay for producing on a piecework basis above a ceiling fixed by the union. The Board reasoned that Congress must have intended to give unions the power to deal with disobedient members by means short of either simply tolerating them or expelling them. ${ }^{39}$

Because it had given unions the power to enforce fines judicially, the Board was forced to restrict a union's power to use those fines. Before Wisconsin Motor, a union could impose fines, but it could enforce them only by the traditional threat of expulsion. ${ }^{40}$ However, in Local 138, International Union of Operating Engineers (Charles $S$. Skura), ${ }^{41}$ the Board limited the unions' new power to enforce fines against members judicially by restricting the reasons for which fines could be imposed. Although it did not directly address the question of court enforcement, the Board held that a union could not fine a member for filing unfair labor practice charges against the umion in violation of a union rule that required members to exhaust imternal union remedies before going to the Board. ${ }^{42}$ After the Board limited a union's power to choose sanctions enforceable by expulsion when the Board deemed the purpose of the sanction improper, it was not surprising that later cases began to erode a union's traditionally unrestricted power to "take any action it desires respecting the acquisition or retention of membership." 43

The Board could not and did not ground its restrictions of union

\footnotetext{
38. 145 N.L.R.B. 1097 (1964).

39. Id. at 1102 .

40. See Minneapolis Star \& Tribune Co., 109 N.L.R.B. 727, 732 (1954) (dismissing claim that imposition of a fine for failure to engage in union activities was $\S 8(\mathrm{~b})(1)(\mathrm{A})$ violation).

41. 148 N.L.R.B. 679 (1964).

42. Id. at 684 .

43. Case No. 1059, Admin. Rulings of the NLRB Gen. Counsel, 35 L.R.R.M. (BNA) 1167 (Nov. 19, 1954); see also notes 30-35 and accompanying text.
} 
disciplinary powers on the express language of the Act or on the legislative history of sections 7 and 8(b)(1)(A). Instead, it rehed upon its assessment of the relative importance of the competing policies involved in each case. The Skura Board stated, "Considering the overriding pubhic interest involved, it is our opimion that no private orgamization should be permitted to prevent or regulate access to the Board . . ."44 Limits on access to the Board inay be, in and of theinselves, a bad thing. What the Board ignored, however, is that in protecting that value by subjecting union disciplinary rules to judicial scrutiny, other values were sacrificed, such as the value of maintaining cohesive unions capable of pursuing uniforin policies. Vimdicating what it perceived to be the policy interest at stake rather than applying the statute hiterally, the Board also opened the door to ideological or philosophical biases entering into the choice of inportant policy interests and the weight to be given them.

\section{B. The Supreme Court Cases}

\section{Allis-Chalmers}

The Supreme Court soon adopted the Board's new position on court-enforced fines. In $N L R B$ v. Allis-Chalmers Manufacturing Co. ${ }^{45}$ a union fined members for crossing a picket line. After some strikebreakers refused to pay the fines, the umon obtained a state court judgment against one strikebreaker for the ainount of his fine. The General Counsel issued a section $8(\mathrm{~b})(1)(\mathrm{A})$ coinplaint challenging the fines against the union, but the Board and later the Supreine Court held that the umion had acted properly. ${ }^{46}$

The Court rejected a hiteral reading of section 8(b)(1)(A) as "highly unrealistic." ${ }^{47}$ Instead, Justice Brennan, for the four member plurahity, ${ }^{48}$ concluded that the section "inust be construed in light of the fact that it is only one of inany interwoven sections in a complex Act, nindful of the inanifest purpose of the Congress to fashion a coherent national labor policy." "49 By stating Congress's purpose in such vague, general terıns,

44. 148 N.L.R.B. at 682.

45. 388 U.S. 175 (1967).

46. Id. at 177-78. Allis-Chalmers addressed only the permissibility of fines assessed against full union members, who choose to belong to a union. The Court reserved the question of whether a similar fine imposed on limited union members would be permissible. Id. at 196-97. In an agency shop, where an employee must belong to a union to keep his job, limited union membership is possible. Limited members are those whose participation in a union is limited to the payment of the mandatory fees and dues of an agency shop.

47. Id. at 179 .

48. Justice White concurred in the opinion though he was "doubtful about the implications of some of its generalized statements." Id. at 199 (White, J., concurring).

49. Id. at 179-80 (quoting NLRB v. Drivers, Local Union No. 639, 362 U.S. 274, 292 (1960)). 
the Court could use an open-ended policy analysis to make new law under section 8(b)(1)(A).

In Allis-Chalmers, the plurality focused on the policy of maintaining the bargaining power of a statutory bargaining agent. The Court noted, "Integral to this federal labor policy has been the power in the chosen union to protect against erosion [of] its status under that policy through reasonable discipline of menibers who violate rules and regulations governing inenibership." 50 The Court found that the tools of expulsion and fines were essential to a union's ability to be an effective bargaining agent. ${ }^{51}$ The Court also noted that provisions for fining inembers were common in union constitutions and bylaws when the Taft-Hartley amendments were adopted..$^{52}$

Although none of the cited union bylaws or constitutions authorized court enforcement of fines, the Court concluded that the possibility of resorting to courts for enforcement "is implicit in any binding obligation, including such union agreenients." 53 The Court likened the unionemployee relationship under a collective bargaining agreement to that established between parties under a contract of sale. ${ }^{54}$ It ignored the dearth of common law cases allowing court enforcement of union fines in order to paint the union-eniployee relationship as a simple common law contractual relation. The Court thus treated external enforcement of umion rules formahistically, as a mere "ineans" to an end, ratler than as an economic weapon that Congress did not specifically give to unions. ${ }^{55}$

The Court then considered how the LMRA changed existing law. The Court acknowledged both Congress's behef that unions had become too powerful ${ }^{56}$ and its desire to insulate an eniployee's job froin his union membership. ${ }^{57}$ The Court also noted that the Taft-Hartley aniendments were designed to leave a union's internal affairs free from state and

50. Allis-Chalmers, 388 U.S. at 181 (footnote omitted).

51. Id.

52. Id. at 181-82.

53. Id. at 182 n.9.

54. Id. at 182 .

55. Id. at 192. Compare the Court's treatment of court enforcement of fines in Allis-Chalmers as a mere "means" of enforcing union rules with earlier cases that reasoned that the "ends" advanced by union disciplinary measures were irrelevant to analysis under $\S 8(\mathrm{~b})(1)(\mathrm{A})$. These cases focused on whether a union's particular "means" of discipline interfered with an employee's freedom to exercise her $\S 7$ rights. See, e.g., the discussion of National Maritine Union, supra note 37, and the discussion of Perry Norvell Co., text accompanying notes 36-37, supra.

To treat court enforcement of union fines as a mere "means" of enforcing valid union rules is to ignore that court enforcement of union fines (fines conceivably greater than an employee's earnings) effectively prevents a union member from working in defiance of union rules. That result is plainly at odds with the LMRA's policy of insulating an employee's job from her union activity. See supra note 11 and accompanying text; $c f$. Allis-Chalmers, 388 U.S. at 204 (Black, J., dissenting).

56. Allis-Chalmers, 388 U.S. at 193 n.32.

57. Id. at 185 . 
einployer interference. ${ }^{58}$ The Court concluded that the proviso in particular evinced a concern with leaving a union's internal affairs alone and inferred front this that the body of section 8(b)(1)(A) must be read so as not to interfere with a urion's internal rules unless those rules affected a inember's employinent status. ${ }^{59}$ However, by characterizing court enforcentent of union fines as simply a "ineans" 60 of enforcing permissible internal disciplinary rules, the Court was able to make the leap necessary to conclude that court-enforced fines, that is, externally conipelled disciplinary nieasures, were internal niatters that the Taft-Hartley aniendnients left to a union's discretion. ${ }^{61}$ Consequently, the Court concluded, court-enforced fines, at least when reasonable, were not coercive within the meaning of section $8(\mathrm{~b})(1)(\mathrm{A})$ when apphed to full union neinbers.

Although the Court based its holding on section 8(b)(1)(A), it also argued that the proviso itself might be used to except court-enforced fines from section $8(b)(1)(a) .{ }^{62}$ The Court's rationale was apparently that court-enforced fines may be less coercive than expulsion in a given case, such as where union neenbership is particularly valuable to an einployee. ${ }^{63}$ However, the Court ignored the point that if expulsion itself is nore coercive than court-enforced fines in a given case, the threat of expulsion would be an effective neans of enforcing union fines without resort to external authority. Indeed, expulsion is actually a less severe sanction than court-enforced fines in cases in which a union might use judicial process to enforce sanctions that it is otherwise unable to enforce by the threat of expulsion.

The argument that expulsion is nore coercive than fines has been

58. Id. at $184-91$.

59. Id. at 195.

60. Id. at 192.

61. Justice Black's dissent, which was joined by three other justices, challenged the majority's view that court-enforced fines could properly be considered internal disciplinary measures. Black argued that placing the coercive power of the state behind union fines could be construed as an internal measure only by a fairly tortured logic. Id. at 203-07 (Black, J., dissenting). More generally, Black attacked the majority's "common law" approach. He argued that a literal reading of the statute, supported by legislative history would properly preclude court-enforced fines against union members. Black wrote:

The real reason for the Court's decision is its policy judgment that unions, especially weak ones, need the power to impose fines on strikebreakers and to enforce those fines in court. It is not enough, says the Court, that the unions have the power to expel those members .... I cannot agree with this conclusion or subscribe to the Court's unarticulated premise that the Court has power to add a new weapon to the union's economic arsenal whenever the Court believes that the union needs that weapon. That is a job for Congress, not this Court.

Id. at 201-02.

62. Id. at 191.

63. Id. at 183. 
undermined by the prohibition of closed shops under the LMRA. ${ }^{64}$ In a standard collective bargaining agreement, a union and an employer establish the terms and conditions of employment. The employer controls the workplace. It determines the rules under which employees shall work, fixes work positions, and determines when an employee will lose his job. However, prior to the enactınent of the LMRA, at least in industries where uniomsm was strong and specialized skills enabled the unions to compel employer acquiescence, ${ }^{65}$ umons had a much greater say in the admimistration and control of workplace rules. This was because unions could insist upon closed shops, in which, either by express agreement or employer default, they determined what constituted compliance with workplace rules and the penalties for noncoinpliance. ${ }^{66}$ A closed shop meant that expulsion from the union would cost an employee his job. Consequently, any ineasure short of expulsion, whether enforced judicially or internally, represented a lesser sanction than expulsion. Once umions lost the power to affect an employee's job position for misconduct, the threat of expulsion lost some of its thunder and was no longer more coercive than a fine enforceable not merely by the threat of expulsion, but by legal process.

Setting aside the proviso, there are several flaws in the Court's argument in Allis-Chalmers. First, the Court made hittle effort to discern the hiteral ineaning of the statute as evinced by its language, the legislative history, and the early case law. There is substantial evidence that Congress intended sections 7 and $8(\mathrm{~b})(1)(\mathrm{A})$ to insulate an employee's job from his orgamizational activity or mactivity ${ }^{67} \mathrm{~A}$ reading of the statute sensitive to this pohicy would give the words "restrain or coerce" their plain meaning. It would restrict only union restraint or coercion that had the effect of limiting the enployment freedom of employees who refrained from assisting their labor organization. This was the intent of the Act's supporters. Given the clarity of the language and intent behind the statute, the Court was not justified in indulging in a form of common law adjudication that purports to develop "a coherent national labor policy,"68 but in fact simply rewrites the statute to fit the apparent equities of a presented case.

The Court's analysis is further flawed by its reliance on the notion that provisions for fines were commonplace in union constitutions and

64. 29 U.S.C. § 158(a), (f) (1982).

65. One example is the typographical unions of International Typographical Union, 86 N.L.R.B. 951, $951-52$ (1949) (unions attempted to maintain closed shop conditions after passage of LMRA through uniform bargaining scheme).

66. See generally Feller, A General Theory of the Collective Bargaining Agreement, 61 CALIF.

L. REV. 663, 718-36 (1973).

67. See supra notes 11-16 and accompanying text.

68. Allis-Chalmers, 388 U.S. at 179-80. 
bylaws when the LMRA was enacted to support its holding allowing court-enforced fines. While such provisions may have been common, the Court's historical argument for the traditional role of court enforcement of union fines is much less convincing. The Court could cite only Master Stevedores' Association v. Walsh, ${ }^{69}$ an 1867 case from the New York Court of Common Pleas, as an example of court enforcement of a "umion" fine. ${ }^{70}$ One may question how closely the business association im that case resembles a twentieth-century labor organization within the context of statutory labor law. Such scant case support exposes how rarely union fines were judicially enforced prior to Allis-Chalmers. An annotation $^{71}$ published about the time of Allis-Chalmers contained only two cases, in addition to Walsh, in which an American court had enforced urion fines. ${ }^{72}$ Court enforcement of union fines was not a traditional form of umion discipline when Congress passed the LMRA. Hence, the absence of an exphicit discussion in the congressional record of the legitimacy of court enforcement of urion fines is not surprising, since legislatures typically direct their attention only to known problems.

Even if court enforcement of fines had been a traditional form of union discipline prior to passage of the LMRA, the statute replaced existing common law. Thus, common law practices do not necessarily have any bearing upon the form union discipline may take within the statutory framework created by the LMRA and NLRA.

The Court also justified court enforcement of fines by erroneously likening the member-union relationship to that of a simple contractual relationship such as exists in commercial dealings. It begs the question to reason that court enforcenrent of fines is implicit as a means of enforcing a "binding obligation"73 between union and member. This argument falsely assumes that the relationship between umion and meniber is on a par with ordinary two-party contracts. A member-union relationship under the LMRA is not a close relative of that existing in ordinary voluntary associations or in contractual relations. ${ }^{74} \mathrm{It}$ is only one of a set of

69. 2 Daly 1 (N.Y. Ct. C.P. 1867 ).

70. Allis-Chalmers, 388 U.S. at 182 n.9. In Walsh the fine was imposed as liquidated damages. The bylaws of the plaintiff incorporated association, of which defendant subscribed, provided that any member of the association found guilty by the association of working for less than the prices fixed by the association should forfeit $25 \%$ of the bill for his work to the assocation. 2 Daly at 2 .

71. Annotation, 13 A.L.R. 3D 1004 (1967).

72. Division 1478 of Almagamated Ass'n of Street, Elec. Ry. \& Motor Coach Employees v. Ross, 90 N.J. Super. 391, 217 A.2d 883 (1966) (reversing dismissal, for lack of jurisdiction on grounds of preemption by LMRA, of union's action to collect fine imposed on member for violation of union rules); UAW Local 756 v. Woychik, 5 Wis. 2d. 528, 93 N.W.2d 336 (1958) (affirming judgment for plaintiff union in action to collect fine for violation of union rule but not addressing legitimacy of court enforcement of union fines).

73. Allis-Chalmers, 388 U.S. at 182 n.9.

74. See Summers, Legal Limitations on Union Discipline, 64 HARv. L. Rev. 1049, 1054-56 (1951). Professor Summers discusses the inadequacy of a contract theory of the union-member 
relationships that exists between an emloyer, a union, and bargaining unit employees within the statutorily defined regime of a collective bargaining agreement. By characterizing the member-union relationship as merely a contractual one, the Allis-Chalmers Court assumed its conclusion and achieved a result plainly at odds with the literal words of sections 7 and $8(\mathrm{~b})(1)(\mathrm{A})$.

In summary, the Court in Allis-Chalmers gave no satisfactory reason for failing to apply sections 7 and $8(b)(1)(A)$ as they were written. In the next major case applying sections 7 and $8(\mathrm{~b})(1)(\mathrm{A}), N L R B$ v. Industrial Union of Marine \& Shipbuilding Workers ${ }^{75}$ (Marine Workers), the Court again displayed this insensitivity to statutory language.

\section{Marine Workers}

In Marine Workers, the Court embraced the $S k u r a^{76}$ doctrine by placing a limiting construction on the section $8(\mathrm{~b})(1)(\mathrm{A})$ proviso. Although the words of the proviso appear to give a union free rein to set its rules concerning the retention of membership, the Court found a section 8(b)(1)(A) unfair labor practice when a union expelled a meinber for filing an unfair labor practice charge against the union without first exhausting mternal union remedies required by the union's constitution. As in Allis-Chalmers, the Court looked beyond Congress's specific intentions in enacting section $8(\mathrm{~b})(1)(\mathrm{A})$ and its proviso and refused to apply the statute hiterally. To determme whether expulsion was permissible, the Court concluded, it was first necessary to see if the constitutional provision concerned "legitimate internal affairs," labor policies were at stake. This resort to malleable concepts of which actions are in the "public domain" and which are properly "internal affairs" of the union ${ }^{78}$ allowed the Court to substitute its judgment for that of Congress in determining which policies should be promoted in a given case.

The Court concluded that the union had committed a section $8(b)(1)(A)$ unfair labor practice without discussing whether the aggrieved member was engaged in the kind of activity sections 7 and 8(b)(1)(A)

relationship. He notes that (1) union constitutions frequently lack the certainty of obligation required for enforceable commercial contracts, (2) the member has no choice in the terms presented to him, and (3) the union is free to unilaterally change the terms of the union-member relation. Id. at 1055. It might be added that the individual employee cannot choose his bargaining representative under statutory labor law, while at common law an employee was free to choose his representative.

75. 391 U.S. 418 (1968).

76. Local 138, Int'1 Union of Operating Eng'rs (Charles S. Skura), 148 N.L.R.B. 679 (1964); see supra text accompanying notes $41-44$.

77. Marine Workers, 391 U.S. at 424

78. Id. at 425 . 
were designed to protect. The Court pulled section $8(\mathrm{~b})(1)(\mathrm{A})$ from its conceptual moorings, and effectively jettisoned the proviso.

The Court agreed with the Skura Board that protecting access to the Board is an overriding public policy when matters within the public domain are at stake. ${ }^{79}$ Because the member's original unfair labor practice charges against the union might have mvolved the employer's conduct as well as the union's, the charges presented matters that the union procedures were "plainly inadequate to deal with." 80 So interpreted, section $8(\mathrm{~b})(1)(\mathrm{A})$ no longer simply guards employees' section 7 rights, but rather iniplements policies the Court finds compelling. ${ }^{81}$

In Marine Workers, the Court refused to give the proviso its literal effect despite abundant legislative history ${ }^{82}$ and early case law ${ }^{83}$ that indicates that the proviso was minended to mean what it says. By refusing to do so, the Court effectively displaced Congress's primary lawniaking role in labor law. In its next major decision in the area, Scofield v. $N L R B,{ }^{84}$ the Court consolidated the principles of Allis-Chalmers and Marine

79. Marine Workers, 391 U.S. at 424. The Court recognized that competing policies were at stake. As in Allis-Chalmers, the Court acknowledged that unions have an institutional interest in maintaiuing discipline and solidarity. But the Marine Workers Court determined (thougl it did not say how) that the interest in promoting access to the Board outweighed the urion's institutional interests.

Justice Stewart dissented in Marine Workers, simply indicating his substantial agreement witl the Third Circuit's opinion. Id. at 428 (Stewart, J., dissenting). The Third Circuit had criticized the Board's position that an "overriding public interest" was violated when a union disciplined an employce in an effort to "limit access to the Board's processes." Industrial Union of Marine \& Shipbuilding Workers, Local 22 v. NLRB, 379 F.2d 702, 706 (3d Cir. 1967), rev'd, 391 U.S. 418 (1968). The Third Circuit concluded that the proviso to $\S 8(\mathrm{~b})(1)(\mathrm{A})$ sliould protect a union's power to expel a member for filing cliarges with the Board if the employee had failed first to exhaust a union's internal appeals process. The court did state that a union could not expel a member under a rule preventing members from ever filing charges witl the Board, but added that a union could pass a rule requiring members to resort first to an internal union appeals process. Id. at 707. The Third Circuit stated that this distinction followed by "logical implication" from the fact that the Act's provisions allowing employees to file charges against a union would be frustrated if a union were always free to expel a complaining inember. This analysis is another variant of the "policy based" approach adopted by the Board and Court, which assumes that the statute- despite its plain language, the strong legislative history, and early cases applying the statute literally-cannot mean what it says.

80. Marine Workers, 391 U.S. at 425.

81. The "policy based" approach of Marine Workers reached its extreme, in formulation if not in application, in the Board's decision in Carpenters Local Union No. 22 (William Graziano), 195 N.L.R.B. 1 (1972). In that case, a trial examiner had found that a union had not violated $\S 8(\mathrm{~b})(\mathrm{l})(\mathrm{A})$ when it fined a member, because the fine served "to implement a legitimate rule which is not in conflict with any policies of the Act." Id. at 6 . In reversing, the Board stated, "In this area, however, as we understand it, we have been specifically charged by the Supreme Court with the duty of determining the overall legitimacy of union interests, and must therefore take into account all Federal policies and not limit ourselves to those embodied in our own Act." Id. at 2 n.5 (emphasis in original).

82. See supra note 19 and text accompanying notes 18-19.

83. See supra note 33 and text accompanying notes $30-33$.

84. 394 U.S. 423 (1969). 
Workers in what has become the leading case on sections 7 and $8(\mathrm{~b})(1)(\mathrm{A})$.

\section{The Scofield Formulation}

In Scofield, the Court returned to the issue of court-enforced union fines. Some union members working on a piecework basis had accepted pay for production in excess of a ceiling set by a union rule. The union fined the employee and went to state court to enforce the fine. The employees in turn filed charges with the NLRB alleging that the union had violated section $8(b)(1)$ by coercing thein to engage in union activities. Affirming the NLRB order finding no violation, the Supreme Court found that the union had a legitimate interest in keeping employee production below the ceiling to reduce pressure by the employer during collective bargaining to set a lower piece-work rate. The Court held that section 8(b)(1)(A) leaves a union free to go to court to "enforce a properly adopted rule which reflects a legitimate union interest, impairs no policy Congress has imbedded in the labor laws, and is reasonably enforced against union meinbers who are free to leave the union and escape the rule." 85 The questions of what are "legitimate union interests," what policies "Congress has imbedded in the labor laws," what reasonable enforcement involves, what "free to leave a union" means, and what effect a member's resignation might have on subsequent disciplinary measures have provided the Board and the courts ample opportunity to reconstruct the law under sections 7 and 8(b)(1)(A).

In subsequent cases, the Supreine Court increinentally refined the Scofield rule. In $N L R B$ v. Boeing, ${ }^{86}$ the Court held that the NLRA did not empower the Board to evaluate the reasonableness of fines, but the Court suggested that the reasonableness of fines could be challenged under state law concerning contracts or voluntary associations. ${ }^{87}$ In $N L R B$ v. Granite State Joint Board, ${ }^{88}$ the Court held that union disciplinary ineasures could not reach members who "lawfully resign" froin the union, but left open the question whether a union could contractually limit its members' power to resign. ${ }^{89}$ Although these cases have clarified some of the ambiguities of the Scofield rule, the doctrine under sections 7 and $8(\mathrm{~b})(1)(\mathrm{A})$ is still largely uncharted by the Supreme Court. The next Part considers the law of union discipline as it has developed in Board and circuit court decisions.

85. Id. at 430. This language defines the zone within which the union is free to enforce its rules under $\S 8(\mathrm{~b})(\mathrm{l})(\mathrm{A})$. By contrast, a union may not enforce a union rule that "invades or frustrates an overriding policy of the labor laws" without violating $\S 8(\mathrm{~b})(1)(\mathrm{A})$. Id. at 429 .

86. 412 U.S. 67 (1973).

87. Id. at 74.

88. 409 U.S. 213 (1972).

89. Id. at 216-17. 
III

\section{The "COMMON LAW" APPROACH}

This Part collects and summarizes cases that describe the contours of the doctrine under section 8(b)(1)(A). Although the LMRA was enacted almost forty years ago, inany innportant issues reinain open. The limits of a union's right to expel nuenibers remain hazy. The question of which union interests outweigh countervailing employee interests still creates ample opportunity for judges to reshape significantly the contours of the union-member relationship. In addition to the uncertainty under the present doctrine, a trend has emerged in Board cases following Scofield of undermining unions' institutional integrity by subjecting internal union affairs to scrutimy under section 8(b)(1)(A). As the cases in this Part illustrate, the "common law" approach adopted by the Court and the Board has resulted in both doctrinal uncertainty and an erosion of unions' mstitutional integrity.

\section{A. Limits on Union Right of Expulsion}

Marine Workers appeared to establish a rule forbidding unions from threatening to expel ineinbers for seeking to use Board process. After all, the Marine Workers Court stated that the concern of protecting an employee's access to the Board represented an "overriding public interest." 90

Later cases indicate that the rule is not so clear. Prior to Marine Workers, the Board had held that unions could permissibly expel inembers for resorting to Board process to decertify the union. ${ }^{91}$ But in International Molders' Union, Local No. 125 (Blackhawk Tanning Co.), ${ }^{92}$ the Board held that unions could not fine inembers for seeking decertification. However, the Board did not suggest that the earher decertification cases should be overruled. Instead, the Board attempted to reconcile the decertification cases with Marine Workers and Skura, which had held that unions could not expel employees for filing unfair labor practice charges with the Board. The three member majority reasoned that the policy of protecting access to the Board, preeminent in Skura and Marine Workers, was trumped in the decertification context by the pohicy

90. NLRB v. Industrial Union of Marine \& Shipbuilding Workers, 391 U.S. 418, 424 (1968).

91. See Tawas Tube Prods., Inc., 151 N.L.R.B. 46 (1965); United Steelworkers, Local No. 4028 (Pittsburgh-Des Moines Steel Co.), 154 N.L.R.B. 692 (1965), petition denied, Price v. NLRB, 373 F.2d 443 (9th Cir. 1967), cert. denied, 392 U.S. 904 (1968).

92. 178 N.L.R.B. 208 (1969), enforced, 442 F.2d 92 (7th Cir. 1971). Compare Blackhawk Tanning Co. with Washington-Baltimore Local, Am. Fed'n of Television \& Radio Artists (WMAR, Inc.), 269 N.L.R.B. 787 (1984) (no unfair labor practice for union to fine and expel member who filed decertification petition and failed to honor lawful picket, when General Counsel failed to prove that the union fined the member for filing the decertification petition rather than for crossing the picket line). 
of permitting unions to defend their status as bargaining representatives. ${ }^{93}$ The Board majority held that, by contrast, fining a member for seeking decertification was an impermissible punitive disciplinary measure. However, the Board suggested that expulsion would be condoned as a merely defensive tactic. ${ }^{94}$

Blackhawk Tanning Co. may approximate the effect, if not the rationale, of applying the statutes literally. A literal approach, however, would permit any disciplinary measure short of expulsion rather than force the all-or-nothing choice of expulsion or acquiescence. It would simply withhold court enforcement of disciplinary measures with the effect of restrictimg a member's exercise of her section 7 rights. By restricting the sanctions that a union may impose and limiting their use to instances in which the Board has determined that the union has a legitimate interest, the present doctrine not only fails to provide clear rules, it also significantly reduces the union's power to regulate its internal affairs. ${ }^{95}$

93. International Molders' Union, Local No. 125 (Blackhawk Tanning Co.), 178 N.L.R.B. at 208.

94. Id. at 209. The Board reasoned that since a union meniber seeking to decertify the union does not value her union menibership, expulsion was not punitive. The Board did not consider, however, whether a fine enforceable only by expulsion (not by the courts) would be more "punitive" than simply expelling the menber. The two member dissent also criticized the najority's distinction between punitive fines and defensive expulsions. Id. at 209-11 (Fanning, A.L.J., dissenting).

95. A union's ability to maintain its institutional integrity has also been undermined by cases using $\S 8(\mathrm{~b})(1)(A)$ to prohibit a union from disciplining a member or withholding membership fronı an aspiring member who testifies against the union in arbitration proceedings. Oil, Chem. \& Atomic Workers Int'l Union, Local No. 4-23 (Gulf Oil Corp.), 274 N.L.R.B. 475 (1985) (unfair labor practice under $\S 8(\mathrm{~b})(1)(\mathrm{A})$, (b)(3), and (d) for union to expel supervisor who testified against union position in arbitration proceedings); Cannery Warehousemen Local Union No. 788 (Marston Ball), 190 N.L.R.B. 24 (1971) (\$ 8(b)(1)(A) unfair labor practice for union to charge, try, and fine meniber for testifying against union position in arbitration proceedings; by undermining the arbitration process, the union's conduct also constituted $\S 8(\mathrm{~d})$ and $\S 8(\mathrm{~b})(3)$ unfair labor practices); International Union of Elec., Radio \& Mach. Workers, Local 745 (National Elec. Coil), 268 N.L.R.B. $308(1983)(\S 8(\mathrm{~b})(1)(\mathrm{A})$ unfair labor practice for union steward to threaten member with a fine if he testified on behalf of the employer in an arbitration hearing), enforced, 759 F.2d 533 (6th Cir. 1985). It is also a $\S 8(\mathrm{~b})(1)(\mathrm{A})$ unfair labor practice for a union to expel members who encourage the filing of unfair labor practice charges. Philadelphia Moving Picture Mach. Operators' Union, Local No. 307 (Velio Iacobucci), 159 N.L.R.B. 1614 (1966), enforced, 382 F.2d 598 (3d Cir. 1967). A union may violate $\S 8(\mathrm{~b})(1)(\mathrm{A})$ by threatening to refuse membership to a traveler from another local who testified against a member of the union in grievance proceedings. Local Union No. 441, Int'l Bhd. of Elcc. Workers (Bear State Elec. Co.), 269 N.L.R.B. 664 (1984). It is also a $\$ 8(b)(1)(A)$ unfair labor practice for a union to refuse membership to an employee who filed unfair labor practice charges with the Board. Machinery Movers Local 136 (United Exposition Serv. Co.), 252 N.L.R.B. 394 (1980). 


\section{B. Countervailing Interests: Uncertainty and the Erosion of Institutional Integrity}

\section{Discipline of Strikebreakers}

Under the Scofield doctrine, the Board has used section 8(b)(1)(A) to regulate the activities at the heart of a union's institutional integrityits power to wage an effective strike. The Board has eroded a union's once unqualified power to mamtain strike discipline through its power to expel strikebreaking meinbers. ${ }^{96}$ Recent Board decisions hold that a union commits a section 8(b)(1)(A) unfair labor practice when it disciplines a nieniber for crossing the union's picket line when the strike is in violation of an existing collective bargaming agreement. ${ }^{97}$ Under this new rule, the Board puts itself $\mathrm{m}$ the role of contract interpreter, ${ }^{98}$ thus usurping the arbitrator's role as primary interpreter of the collective bargaining agreeinent. ${ }^{99}$ Furthermore, the Board has applied this rule even when it is uncertain whether an employer has complied with its duty to arbitrate, which is norinally seen as the quid pro quo ${ }^{100}$ of a binding no-strike clause. ${ }^{101}$ The Board has also found that union discipline of strikebreakers following an amnesty agreement between the union and the einployer

96. See supra note 33 and text accompanying notes $33 \& 35$.

97. Laborers Local No. 135 (Bechtel Power Corp.), 271 N.L.R.B. 777, 779 (1984) $(\S 8(\mathrm{~b})(1)(\mathrm{A})$ unfair labor practice to fine or threaten to fine, and to bring or threaten to bring internal union charges against members who refuse to participate in a strike that violates the collective bargaining agreement); Mississippi Gulf Coast Bldg. \& Constr. Trades Council (Roy C. Anderson, Jr., Inc.), 222 N.L.R.B. 649 (1976) (\$ 8(b)(1)(A) unfair labor practice to fine members for not respecting picket line wheu the collective bargaining agreement contained a valid no-strike clause), enforced, 542 F.2d 573 (5th Cir. 1976).

Compare these cases with an early case, Perry Norvell Co., 80 N.L.R.B. 225, 240 (1948), in which the Board held that a union did not commit a $\S 8(\mathrm{~b})(1)(\mathrm{A})$ unfair labor practice by calling a strike in violation of the collective bargaining agreement, noting that Congress had expressly considered and then rejected making violation of the terms of a collective bargaining agreement an unfair labor practice. See supra notes 36-37 and accompanying text.

98. See Local 12419, Int'l Umion of District 50 (National Grinding Wheel Co.), 176 N.L.R.B. 628 (1969) (Board interpreted the first union's no-strike clause to prohibit sympathy strikes and thus found a $\S 8(\mathrm{~b})(1)(\mathrm{A})$ unfair labor practice when union disciplined members for crossing another union's lawful picket line); United Food \& Commercial Workers Union, Local No. 1439 (Joe Hagood), 275 N.L.R.B. No. 7, 1985-1986 NLRB Dec. (CCH) ๆ 17,268 (Apr. 9, 1985) (rejecting administrative law judge's interpretation of the collective bargaining agreement, the Board construed the no-strike clause to cover sympathy strikes, so that union committed $\S 8(\mathrm{~b})(1)(\mathrm{A})$ unfair labor practice by threatening members with discipline for crossing sister union's lawful picket line).

99. United Steelworkers v. American Mfg. Co., 363 U.S. 564, 567-68 (1960) ("The function of the court is very limited when the parties have agreed to submit all questions of contract interpretation to the arbitrator. It is confined to ascertaining whether the party seeking arbitration is making a claim which on its face is governed by the contract.").

100. Textile Workers Union v. Lincoln Mills, 353 U.S. 448, 455 (1957) ("Plainly the agreement to arbitrate grievance disputes is the quid pro quo for an agreement not to strike.").

101. International Molders Union, Local No. 164 (Pacific Steel Casting Co.), 270 N.L.R.B. 1105 (1984), enforced, 765 F.2d 858 (9th Cir. 1985). The Ninth Circuit upheld the Board's holding that a union violated $\S 8(\mathrm{~b})(1)(\mathrm{A})$ when the union disciplined members for refusing to honor a strike the union alleged was lawful despite a no-strike clause in the collective bargaining agreement. The 
is an unfair labor practice under section $8(\mathrm{~b})(\mathrm{l})(\mathrm{A}) .^{102}$

Beyond forbidding union discipline of menibers who refuse to support a strike that conflicts with the union's agreement with the employer, other cases have held that a union may not discipline strike breakers and picket-line crossers when the union's strike or picket line is in conflict with other rules or policies of the Act. For example, a union violated section $8(\mathrm{~b})(1)(\mathrm{A})$ by disciplining a meniber who crossed another union's picket line because the disciplining union failed to give proper notice under section $8(\mathrm{~g})$ of its intention to respect the picket line. ${ }^{103} \mathrm{~A}$ union violated the section by disciplining members for working behind a lawful picket line when the union was held to have an nitent to cause the menibers to quit working for a neutral enuployer doing business with the struck employer. ${ }^{104}$ It was also a section $8(\mathrm{~b})(1)(\mathrm{A})$ unfair labor practice for a union to fine or threaten to fine nienibers who crossed the union's picket line when the picket line violated section 8(b)(4). ${ }^{105}$ Numerous other instances of strikebreaker disciphine have been held to violate section $8(\mathrm{~b})(1)(\mathrm{A})$ when the underlymg strike is found unlawful. ${ }^{106}$

Other recent cases have further coniphicated the law on union discipline of strikebreakers. The decisions discussed thus far suggest that when a union's strike or picket line is lawful (absent, of course, a subsequent amnesty agreement with an eniployer ${ }^{107}$ ), a union is free to discipline its members. The Board has determined, however, that it is necessary to analyze a union's notives. When improper notives lurk behind otherwise proper disciplinary procedures, a union violates section $8(\mathrm{~b})(1)(\mathrm{A})$.

For instance, a union may violate section $8(\mathrm{~b})(1)(\mathrm{A})$ by fining mem-

union had maintained that the clause was not applicable because the employer had refused to honor an arbitration award pending judicial review.

102. Office \& Professional Employees Int'1 Union, Local 129, 267 N.L.R.B. 1017, 1021 (1983) $(\S 8(b)(1)(A)$ unfair labor practice for union to charge, try, and fine members for breaking a lawful strike, where union had agreed to amnesty provisions in a strike settlement agreement).

103. NLRB v. Stationary Eng'rs, Local 39, 746 F.2d 530 (9th Cir. 1984).

104. Ventura County Dist. Council of Carpenters (Commercial Indus. Constructors, Inc.), 259 N.L.R.B. 541, 546 (1981). The Board held that the union committed a $\$ 8(\mathrm{~b})(4)$ unfair labor practice as well.

105. Mississippi Gulf Coast Bldg. \& Const. Trades Council (Roy C. Anderson, Jr., Inc.), 222 N.L.R.B. 649, enforced, 542 F.2d 573 (5th Cir. 1976). The Board also based its holding on the strike's illegality under the collective bargaining agreement. See supra note 97 and accompanying text.

106. See NLRB v. Retail Clerks Union, Local 1179, 526 F.2d 142, 146 (9th Cir. 1975) (union violates $\S 8(\mathrm{~b})(1)(\mathrm{A})$ by fining or refusing to transfer membership of member who refused to respect second union's picket which was later determined to violate $\S 8(\mathrm{~b})(7))$; Communications Workers, Local 1127 (New York Tel. Co.), 208 N.L.R.B. 258, 265 (1974) (union violates § 8(b)(1)(A) by fining members who abandon strike that started before end of 60 -day notice period required by $\S 8$ (d) and by demanding strikebreaking members to return strike assistance money received during participation in strike).

107. See supra note 102 and accompanying text. 
bers who cross the lawful picket of a second union although it would have been lawful for the employees to respect the picket line voluntarily. In United Association of Journeymen, Local 444 (T.S. Hanson Plumbing), ${ }^{108}$ the Board reasoned that although the union claimed a legitimate interest in gaining the cooperation of its sister union in case of future strikes, the union im fact had a proscribed secondary objective of hurting a neutral enıployer who was doing business with a lawfully struck eniployer. In another case, a umion had fined members for crossing a lawful picket line. The Board found a section $8(\mathrm{~b})(1)(\mathrm{A})$ violation, reasoning that although the fines were stated to be for the purpose of disciplining strikebreakers, the union actually intended to punish the inenibers for filing unfair labor practice charges against the union, filing a decertification petition against the union, voting against the umion in the ensuing election, and giving testimony against the union im unfair labor practice proceedings. ${ }^{109}$ A doctrine that turns on umion inotives rather than acts gives the Board substantial discretion in using section $8($ b)(1)(A) to regulate the union-member relationship.

\section{Other Examples of Doctrinal Uncertainty and Erosion of Union Disciplinary Powers}

Apparently, a union sometimes can, and sometinies cannot, discipline a meniber who volunteers information to his employer that results in discipline or discharge of a fellow meniber by the eniployer. In Oil, Chemical \& Atomic Workers International Union, Local 7-103 (DAP, Inc.), ${ }^{110}$ the Board found that a union violated section 8(b)(1)(A) by fining members who provided statements to their eniployer claiming that a fellow meniber had damaged the eniployer's property. The inembers were treated by the Board as cooperating with the grievance machinery, even though no grievance had then been filed. The Board found it clear that the grievance machinery would be activated once the eniployer discharged the accused eniployee. ${ }^{111}$ By contrast, in Local 5795, Communications Workers (Western Electric Co.), 112 the Board found no unfair labor practice when a union fined a member who reported to the employer that a fellow member had violated a company rule by having a bottle of alcohol at the machine she was operating. ${ }^{113}$

In other cases, the Board has undercut a union's institutional integrity by using section $8(\mathrm{~b})(1)(\mathrm{A})$ to enforce policies it considers iniportant

108. 277 N.L.R.B. No. 137, 1985-1986 NLRB Dec. (CCH) ๆ 17,765 (Dec. 23, 1985).

109. Automotive Salesmen's Ass'n (Spitler-Demmer, Inc.), 184 N.L.R.B. 608 (1970).

110. 269 N.L.R.B. 129 (1984).

111. Id. at 131.

112. 192 N.L.R.B. 556 (1971).

113. Id. 
in a particular case. A union may commit a section $8(\mathrm{~b})(1)(\mathrm{A})$ unfair labor practice by attenupting to enforce a union rule that calls for members to refrain from certain duties under an existing collective bargaining agreement as a means of bringing economic pressure to bear on an employer in the negotiations leading to a new contract. In one case, the Board held that a union had committed an unfair labor practice by prohibiting its menibers from working contractually mandatory overtime by imposing $\$ 500$ fines for each violation of the ban. The Board reasoned that the ban violated section 8(b)(1)(A) since the union's purpose was to put economic pressure on an eniployer to encourage concessions in the negotiations for a new contract. ${ }^{114}$ In another case, the Board held that a union violated section $8(\mathrm{~b})(1)(\mathrm{A})$ by threatening disciplinary action, including court-enforced fines, if members continued to perforn their employer's warranty work. The Board concluded that the union had the impermissible objective of attempting to achieve unilateral midterm modification of the collective bargaining agreenient. ${ }^{115}$

The cases involving union denial of health benefits supplied and adnimistered by a union as a disciphinary measure against inembers who disregard union rules provide a good example of the uncertainty created by the "cominon law" approach. In National Association of Letter Carriers (United States Postal Service), ${ }^{116}$ the Board found that there was no unfair labor practice when a union withheld participation in its health plan from members who accepted supervisory positions in violation of a union rule. ${ }^{117}$ But in Teamsters Cannery Local No. 670 (Stayton Canning Co. Cooperative), ${ }^{118}$ the Board concluded that a union had violated section $8(\mathrm{~b})(1)(\mathrm{A})$ by denying its financial core nieinbers access to unionprovided healthcare services. The Board deterinined that it was of no significance that the benefits were outside the collective bargaining agreement. The Board reasoned that the denial had the foreseeable effect of coercing members into joining the union as full inembers, in violation of their right to refrain from doing so. ${ }^{119}$ In an earher case, Amalgamated Local 286, UAW (Harold Vlasak), 120 the Board had found that a union coinunitted a section $8(\mathrm{~b})(1)(\mathrm{A})$ unfair labor practice by threatening to deprive nembers of the benefit of insurance adıninistered by the union under the collective bargaining agreement. However, in Vlasak, the

114. Graphic Communications Union, Local 229 (Daily Printing Inc.), 272 N.L.R.B. 1088 (1984).

115. Sheet Metal Workers Int'1 Ass'n, Local No. 16 (Brod \& McClung-Pace Co.), 270 N.L.R.B. 116 (1984). The Board concluded that the conduct also constituted a $\S 8(\mathrm{~b})(3)$ unfair labor practice.

116. 240 N.L.R.B. 519 (1979).

117. Id. The Board also found it permissible for the union to expel such members.

118. 275 N.L.R.B. No. 127, 1985-1986 NLRB Dec. (CCH) \& 17,371 (June 28, 1985).

119. Id.

120. 110 N.L.R.B. 371 (1954), enforcement denied, 222 F.2d 95 (7th Cir. 1955). 
Board did not dispute the trial examiner's legal conclusion that if the benefits administered had been outside the terms and conditions of employment under the collective bargaining agreement, the union would have been free to withhold them. ${ }^{121}$ This earlier view had the advantage of leaving a union complete freedom to administer umion funds. At the same time, a union could not violate the duty of fair representation by discriminating on the basis of union activity in deciding how to distribute funds or perks provided by the employer.

The Board has also used section 8(b)(1)(A) to regulate a union's control of information or propaganda that is disseminated in the name of the umion, by soine faction of the union, or by using a union inedium of cominunication. For instance, the Board found a section 8(b)(1)(A) unfair labor practice when a union brought disciplinary charges agamst nembers who promulgated election propaganda critical of union officials. ${ }^{122}$ In another case, the Board found that a union violated section 8(b)(1)(A) when it charged, tried, fined, and reported to a state unemployement agency (for refusing a job while applying for state benefits) a meniber who published materials critical of union hierarchy. ${ }^{123}$ The Board, however, found no unfair labor practice when a union renioved front its bulletin board material posted by a member criticizing the union and its leaders, because the union did not discipline or threaten discipline of the niember, like material was distributed in the employee breakrooin without einployer or union action, and an all-purpose bulletin board was available for the member's use. ${ }^{124}$ These cases illustrate the difficulty of predicting which facts the Board or the courts will find significant enough to justify regulation of union conduct. More iniportantly, the cases illustrate how the present doctrime permits judicial supervision even of such internal union affairs as the pronulgation of union-sponsored information.

Institutional integrity has been further eroded under the Scofield doctrine by Board cases holding that a union is limited in the disciplinary measures it can take against nembers who voted against the union in representation elections ${ }^{125}$ or who go to the Board seeking to have the

121. Id.

122. Local Lodge No. 707, Int'l Ass'n of Machinists (Pratt \& Whitney), 276 N.L.R.B. No. 105, 1985-1986 NLRB Dec. (CCH) II 17,955 (Sept. 30, 1985).

123. Local 139, Int'l Union of Operating Eng'rs (Wisconsin Chapter, Associated Gen. Contractors, Inc.), 273 N.L.R.B. 992 (1984), enforcement granted in part and denied in part, 796 F.2d 985 (7th Cir. 1986).

124. Teamsters Local 515 (Roadway Express, Inc.), 248 N.L.R.B. 83 (1980), petition granted sub nom. Helton v. NLRB, 656 F.2d 883 (D.C. Cir. 1981).

125. See Machine Stone Workers Local 89 (Bybee Stone Co.), 265 N.L.R.B. 496 (1982) $(\S 8(\mathrm{~b})(1)(\mathrm{A})$ unfair labor practice for union to fine members who voted against it in a representation election, but expulsion permissible). 
bargaining unit reduced. ${ }^{126}$

Under the Marine Workers rule, the Board has regulated internal matters at the heart of a union's imstitutional integrity-control of its officers and stewards and control of lines of authority in the union. The Board has held that a union commits an unfair labor practice by disciplining officers and stewards by removing then from office or menibership when they file unfair labor practice charges against the union or testify against the union in grievance or unfair labor practices proceedinigs.

For example, a union committed a section $8(\mathrm{~b})(1)(\mathrm{A})$ unfair labor practice by adopting and enforcing a rule forbidding nieinbers fronı accepting teniporary supervisory positions with the eniployer. ${ }^{127}$ In another case, the Board found that a union violated section $8(\mathrm{~b})(1)(\mathrm{A})$ by removimg a niember fron his position as shop steward because he filed unfair labor practice charges with the Board. ${ }^{128}$ The Board went so far as to hold that an international union committed a section $8(\mathrm{~b})(1)(\mathrm{A})$ unfair labor practice by disciplining and removing a local president for filing unfair labor practice charges against the union. The Board even ordered the umion to remstate the dissident president. ${ }^{129}$ The Board also found that a union violated the section by reinoving a member from his position on the union's fair einploynent practices comnittee for filing unfair labor practice charges against the umon. ${ }^{130}$ In contrast, the Board held that a union could remove a ineinber from his position as chairman of the plant safety committee for supporting a different candidate for the union presidency than did the union hierarchy. The Board reasoned that a member who is hostile to or in disagreement with the union leadership may be undesirable or ineffective in carrying on her responsibilities as a union representative. ${ }^{131}$ Why this reasoning did not control in the other

126. See Buffalo Newspaper Guild, Local 26 (Buffalo Courier Express, Inc.), 265 N.L.R.B. 382 (1982) $(\$ 8(b)(I)(A)$ unfair labor practice for union to try member for filing unit clarification petition with the Board for the purpose of having some supervisors removed from the bargaining unit).

127. Communications Workers, Local 1170 (Rochester Tel. Corp.), 194 N.L.R.B. 872, enforccd, 474 F.2d 778 (2d Cir. 1972). The Board also found a $\$$ 8(b)(3) unfair labor practice.

128. Teamsters Local 79 (Carl Subler Trucking, Inc.), 269 N.L.R.B. 1132 (1984); cf. General Am. Transp. Corp., 227 N.L.R.B. 1695 (1977) (union violated $\S 8(\mathrm{~b})(1)(\mathrm{A})$ by removing steward from that position when he refused to withdraw unfair labor practice charges filed against the employer), enforcement denied sub nom. NLRB v. International Bhd. of Boilmakers, 581 F.2d 473 (5th Cir. 1978). But see National Ass'n of Letter Carriers (United States Postal Serv.), 240 N.L.R.B. 519 (1979) (no unfair labor practice for union to withhold participation in its health plan from members who accept supervisory positions in violation of union rule; also no unfair labor practice to expel such members).

129. International Ass'n of Bridge, Structural \& Ornamental Iron Workers (Walker Constr. Co.), 277 N.L.R.B. No. 99, 1985-1986 NLRB Dec. (CCH) \ 17,692 (Dec. 13, 1985), supplemented by 279 N.L.R.B. No. 123, 1985-1986 NLRB Dec. (CCH) П 17,939 (May 13, 1986).

130. Local 212, UAW (Chrysler Corp.), 257 N.L.R.B. 637 (1981), enforced, 690 F.2d 82 (6th Cir. 1982).

131. Shenango Inc., 237 N.L.R.B. 1355 (1978). The Board did find a $§ 8(b)(1)(A)$ unfair labor 
cases discussed is hard to discern.

\section{Restrictions on Resignations During or Pending a Strike}

Examining the doctrine concerning union discipline of nembers who attenipt to resign before misconduct to avoid union fines provides a good illustration of the flaws of the Court's common law approach. Although this straightforward issue has recently been resolved, at least temporarily, by a Suprenie Court decision, it took years of adjudication. The wide disparity of decisions on the matter denionstrates the unpredictability and manipulability created by the Court's approach.

Scofield left open the question whether a union could discipline a former meniber who resigned to escape union rules. In $N L R B$ v. Granite State Joint Board, ${ }^{132}$ the Court held that an employee who "lawfully resigns" from a union may not be disciplined for subsequent violations of union rules. ${ }^{133}$ Since that decision, several courts of appeal and Boards have considered whether and when a union can restrict a meniber's freedom to resign to ensure comphiance with internal rules. Applying the Scofield approach to section 8(b)(1)(A), a court or Board could reach alniost any answer to the question of what restranits on resignation are permissible. As the case law developed, almost every possible answer to the question was entbraced at some time by some circuit or Board.

For example, im Machinists Local 1327 v. NLRB, ${ }^{134}$ the Ninth Circuit held that when a umion's constitution stated that an eniployee could not resign during or fourteen days preceding a strike, the union could judicially enforce fines against strikebreaking members who resigned in violation of the constitutional rule. ${ }^{135}$ Looking to the union's "legitimate interests," the court concluded that a umion needed the power to discipline strikebreaking members $\mathrm{m}$ order to protect its bargaming position. ${ }^{136}$ Although the court recognized the employees' section 7 interest in freedom to resign from union activity, ${ }^{137}$ it believed that the union rule, which allowed a member to either leave her employment or work within the union to end the strike, represented a reasonable restriction on this freedom. ${ }^{138}$

The Seventh Circuit, in Pattern Makers' League v. $N L R B,{ }^{139}$ came

practice, however, because the union had threatened reprisals against the dissident member for selling tickets and distributing propaganda on behalf of a union faction.

132. 409 U.S. 213 (1972).

133. Id. at 214-15.

134. 725 F.2d 1212 (9th Cir. 1984), vacated and remandcd, 105 S. Ct. 3517 (1985).

135. Id. at $1215-16$.

136. Id. at 1217.

137. Id.

138. Id. at 1216-18.

139. 724 F.2d 57 (7th Cir. 1983), aff'd, 105 S. Ct. 3064 (1985). 
to a contrary conclusion. The court, reviewing a similar resignation restriction, held that it was a section $8(\mathrm{~b})(1)(\mathrm{A})$ unfair labor practice for a union to punish members who resigned during a strike to avoid discipline for disobeymg union strikebreaking rules. ${ }^{140}$ The court recognized a union's "powerful" interest in mamtaining strength during a strike, but concluded that this interest was overridden by the employees' interest in refraining from concerted activity. ${ }^{141}$

Similarly, the Boards that have considered the effect of employee resignation proposed three different rules in two cases. In the first case, Machinists Local 1327 (Dalmo Victor), ${ }^{142}$ a Board majority invalidated a union rule prohibiting members from resigning during or fourteen days prior to a strike. The two Board members who gave "the rule" of Dalmo Victor presented a unique solution to the knotty problem of balancing a union's interest in maintaining strike solidarity through restrictions on resignations and the competimg employee imterest in freedom to refrain from union activity. Although concluding that neither interest was overriding, they nevertheless held that the restriction was unreasonable because it was of potentially infinite duration. ${ }^{143}$ However, the two members determined that a union bylaw nuaking resignations effective on thirty days notice, regardless of whether a strike was on, would be valid as a reasonable conipromise of the interests at stake. ${ }^{144}$ Two other members, concurring in the result, thought that any limitation on an employee's right to resign was invalid under the Act. ${ }^{145}$

One Board member dissented in Dalmo Victor. He argued that a union's interest im maintaining its position as an effective bargaining agent justified "reasonable" restrictions on the right to resign and found the restriction in the case at hand reasonable. ${ }^{146}$

Perhaps because the Board's membership changed and so too its view of significant policies, the Board later changed its position. In International Association of Machinists, Local Lodge 1414 (Neufeld PorscheAudi, Inc.), ${ }^{147}$ the Board held that a union could place no restrictions on an employee's right to resign and thereby escape court-enforced fines for subsequent misconduct. ${ }^{148}$

The Supreme Court temporarily resolved the conflict in Pattern

140. Id. at 58 .

141. Id. at 60 .

142. 263 N.L.R.B. 984, 987 (1982), enforcement denied, 725 F.2d 1212 (9th Cir. 1984), vacated, 105 S. Ct. 3517 (1985).

143. Id. at 986.

144. Id. at 987.

145. Id. at 992.

146. Id. at 995 .

147. 270 N.L.R.B. 1330 (1984).

148. Id. at 1336. 
Makers' League v. NLRB. ${ }^{149}$ In the plurality opinion, Justice Powell, joined by three other Justices, concluded that the Court should defer to the Neufeld Porsche-Audi Board's interpretation of section 8(b)(1)(A): "We believe that [section] 8(b)(1)(A) properly may be construed as prohibiting the fining of employees who have tendered resignations ineffective under a restriction in the union constitution."150 Justice White concurred, agreeing that the Board "adopted a sensible construction of the imprecise language of [sections] 7 and 8 that is not negated by the legislative history of the Act."151 However, he expressly qualified his concurrence by noting: "[W]ere the Board arguing for [the union's] interpretation of the Act, I would accord its view appropriate deference."152

Consequently, although Pattern Makers' resolves the conflict in the courts, it does not provide a definitive interpretation. Because the Court simply accepts the Board's current position, the decision leaves open the possibility that some future Board may uphold once again restrictions on the power to resign. ${ }^{153}$ Thus, the case does not undo the potential for hitigation engendered by the common law approach.

Although similar in the results it produces, the Neufeld PorscheAudi rule, approved by the Pattern Makers' Court, differs significantly froin the hiteral approach discussed earher. Under the literal approach to section $8(\mathrm{~b})(1)(\mathrm{A})$, a union meinber could always escape disciplinary actions designed to enforce participation in collective activity by resigning from the union. ${ }^{154}$ Under Neufeld Porsche-Audi, a union member can escape disciphine only if he resigns before his misconduct. ${ }^{155}$ The latter rule thus handicaps legally unsophisticated employees who are not aware that resignation restrictions are not legally binding.

Even if the Board extended the Neufeld Porsche-Audi rule so that resignation ended a union's power to discipline members altogether, the literal approach would still offer better results. If resignation ended a union's power to discipline, an informed employee would never suffer the

149. 105 S. Ct. 3064 (1985), affg 724 F.2d 57 (7th Cir. 1983).

150. Id. at 3068.

151. Id. at 3076.

152. Id. at 3077.

153. In a dissent joined by two other Justices, Justice Blackmun discussed common law rules concerning voluntary associations, congressional interest in creating strong collective bargaining agents, and the proviso to $\S 8(\mathrm{~b})(1)(\mathrm{A})$. He concluded that the Act permits a union to restrict members' resignations in order to preserve its collective strength. Id. at 3077-84 (Blackmun, J., dissenting). In a separate dissent, Justice Stevens accepted Blackmun's reasoning and added that the "plain language in the proviso to $\S 8(\mathrm{~b})(1)(\mathrm{A})$ " convinced him that a union could restrict a member's right to resign. Id. at 3085 (Stevens, J., dissenting).

154. See supra text accompanying note 20.

155. See Newspaper Guild, Local 3 (New York Times Newspaper), 272 N.L.R.B. 338, 338 (1984) (no unfair labor practice for union to fine members who crossed picket line before submitting resignations to the union; portion of fines attributable to members' post-resignation conduct should be rescinded). 
court-enforced fines Allis-Chalmer countenances unless he so valued his inembership that he was unwilling to resign to escape discipline. If that were the case, however, the mechanisin of court enforceinent would be unnecessary - a union's threat of expulsion would conipel the einployee to pay his fine. On the other hand, to the extent einployees subnitted to court-enforced union fines that they could otherwise escape through resignation, an extension of Neufeld Porsche-Audi still would put an unnecessary premium on legal sophistication. By simply forbidding courtenforced fines, the Court could ensure that even an unwary or uncounseled einployee who failed to resign before breaking a union rule enjoyed the same protections legally sophisticated employees enjoy under the Board's present rule.

\section{Critique of the Common Law Approach}

In support of the Board's current position, it may be argued that many of the union practices at issue are bad and should be prohibited through the mechanism of unfair labor practice liability under section 8 (b)(1)(A), or by limiting a urion's power to expel. There are several responses to this contention.

To begin with, the easy response is that it is not the function of the Court or the Board in effect to write new unfair labor practices provisions into the NLRA under the pretense of statutory construction. The Court and the Board lack both the pohtical accountability and policyinaking competence to decide which federal policies should be preeminent in labor law.

Second, much of the union misconduct in the cases described above is prohibited by other unfair labor practices provisions and other sections of the LMRA. For instance, if a strike violates a collective bargaining agreeinent and the umion refuses to arbitrate, an employer can in many instances obtain an injunction under the Act. ${ }^{156}$ Similarly, a union picket line made with an improper secondary objective constitutes a section $8(b)(4)$ unfair labor practice. ${ }^{157}$ Union inembers who are disciplined for criticizing union officials or speaking on behalf of union reform have remedies in federal court under the LMRDA. ${ }^{158}$ Thus, the Scofield doctrine has not, for the inost part, rendered formerly lawful union conduct

156. See Boys Mkts., Inc. v. Retail Clerks Union, Local 770, 398 U.S. 235 (1970) (strike may be enjoined if it is over an arbitrable issue and in violation of a no-strike clause). But see Jackson Bulk Terminals, Inc. v. International Longshoremen's Ass'n, 457 U.S. 702 (1982) (strike that is part of a political protest cannot be enjoined since it is not over an arbitrable issue); Buffalo Forge Co. v. United Steelworkers, 428 U.S. 397 (1976) (a sympathy strike cannot be enjoined since it is not over an arbitrable issue).

157. See 29 U.S.C. $\S 158(b)(4)$ (1982).

158. Labor-Management Reporting and Disclosure Act of $1959 \S \S 101(a), 102,29$ U.S.C. $\S \S 411(\mathrm{a}), 412$ (1982). 
unlawful; rather, it has created new remedies for conduct already unlawful. ${ }^{159}$ Even though these remedies may serve to vindicate important, congressionally chosen pohicies, it is mistaken to separate those policies from the remedies explicitly chosen by Congress to enforce them.

For example, a union uses a secondary boycott against an employer with which it is negotiating to apply economic pressure, which is normally a legitimate enterprise for a umion. But Congress has recognized that there must be limits to the economic weapons employers and unions use in their adverserial relations. Consequently, the Act makes certain kinds of secondary boycotts an unfair labor practice. ${ }^{160}$ However, Congress did not make secondary boycotts a crime, nor did it provide for fines against a union that engages in a secondary boycott. Rather, Congress gave employers discrete weapons, mcluding unfair labor practices provisions, mandatory injunctions, and damage actions, with which to attack improper secondary boycotts. In creating new unfair labor practice hability that interferes with the niternal affairs of unions, the courts and the Board have usurped Congress's role of distributing economic weapons between employers and unions. ${ }^{161}$

The legislative history of the Act clearly shows, ${ }^{162}$ as the Supreme Court recognized in Allis-Chalmers, ${ }^{163}$ that Congress in 1947 was not niterested $\mathrm{m}$ regulating the internal affairs of unions. Indeed, it was not until 1959, with passage of the LMRDA, ${ }^{164}$ that Congress first imposed restrictions on union disciplinary measures. Even then, it did not outlaw all union sanctions opposed to the policies of the NLRA. Rather, it provided remedies in the district courts, not before the Board, for union measures restricting speecli, assembly, or violating certam procedural requirements. ${ }^{165}$ For the Board to stand in judgnient of internal rules affecting union membership seems plainly contrary to Congress's intent to keep the Board out of unions' niternal affairs.

\section{IV}

\section{The Case for a Literal ApProach}

The scheme of employee-union relations created by hiteral apphica-

159. For instance, while it is a $\S 8(\mathrm{~b})(1)(\mathrm{A})$ unfair labor practice for a union that lacks majority support to bargain with an employer, International Ladies' Garment Workers' Union v. NLRB, 366 U.S. 731 (1961), under the Marine Workers exception the Board now regulates union disicipline of members who contest its majority status. See supra text accompanying notes 91-94.

160. 29 U.S.C. § 158(b)(4).

161. This is especially true in the cases where the Board has found $\S 8(\mathrm{~b})(1)(\mathrm{A})$ unfair labor practices for union sanctions against members who refuse to strike in violation of a collective bargaining agreement. See discussion of Perry Norvell Co., supra note 33.

162. See supra notes $18-19$ and accompanying text.

163. See supra note 58 and accompanying text.

164. See infra note 169 and accompanying text.

165. See 29 U.S.C. $\$ \S 411,412$ (1982). 
tion of sections 7 and $8(\mathrm{~b})(1)(\mathrm{A})$ is consistent with the plain words of those sections. It is consistent with the legislative history of the TaftHartley amendments: Congress intended to place restrictions on union coercion of einployees paralleling those placed on employers by the original NLRA. Furthermore, the early cases support the view that sections 7 and $8(\mathrm{~b})(1)(\mathrm{A})$ were intended to give unions unrestricted power to expel members. This Part argues that the literal approach described contributes to a workable scheme of employee-union relations.

The literal approach would not only conform to the purposes behind the LMRA, it also would provide an administratively efficient scheme for regulating einployee-union relations. It would not engender the large aniount of litigation of the present approach. Instead of weighing conlpeting individual and institutional interests in an inevitably unprincipled balancing test, the literal approach would leave union-einployee disputes a purely internal union niatter. An employee and a union could each weigh its interest in inaintaining their association.

The hiteral approach would provide a zone in which an eniployee could exercise his section 7 rights without fear of eniployer or union retaliation. ${ }^{166}$ Counterpoised to this would be the eniployer's power to set the rules of the workplace, and the union's power to both represent all the enployees in a bargaining unit and establish the conditions for participation in the union. By allowing employees to opt out of assisting union policies, this approach would mitigate the involuntary unionism that results from the systen of majority representation. At the same time, unions would be able to protect their effectiveness in the face of external employer opposition through their power to expel dissident or disruptive inembers.

If instead judicial exceptions are carved into a union's statutory right to determine its nembership rules, it beconies harder for unions to naintam internal discipline or to prevent possibly divisive dissent. Although such limitations on union control of members may serve to further democratize umons, unions, like all voluntary associations, inust protect individual interests through the force of numbers and collective economic strength. ${ }^{167}$ When a voluntary association is compelled by the state to accept dissident members, the association's ability to niaintain a united purpose in the face of external opposition is undermined and its effectiveness in protecting or achieving its inembers' ainis is reduced.

Of course, under the NLRA, unions are the exclusive bargaining representatives of the eniployees in a bargaining unit as a matter of statu-

166. This is in accord with the concern often expressed by the Taft-Hartley Congress that an employee's job be insulated from employer or union retataliation when he engages in or refrains from collective activity. See supra notes 11 \& 12 and text accompanying note 11 .

167. See generally R. NisBet, COMMUNITY AND POWER (1962). 
tory law and not through unanimous employee consent. Consequently, unlike members of other voluntary associations (for example, churches, professional associations, or fraternal organizations), an employee rejected by his statutory bargaining agent cannot seek another or escape the effects of its pohicy-making power over the terms and conditions of his employment. The LMRA compensates for this, however, by imposing a duty of fair representation on unions, which prevents them from discrimmating agamst nonunion employees in bargaining for the terms and conditions of employment. ${ }^{168}$

It is better that external law, such as civil rights legislation or constitutional principles, create specific exceptions to a union's, or more generally, a voluntary association's, power to set its own membership rules than it is that courts engage im ad hoc rulemaking. Notably, Congress has created specific exceptions in a number of areas ${ }^{169}$ where it has perceived a need to regulate the union-nember relationship. It is not within the competence of the courts or the Board to determine what forin the union-member relationship should take.

The appeal of a hiteral approach is not based solely on abstract concerns for judicial competence and the integrity of voluntary associations. Literal application of sections 7 and $8(b)(1)(A)$ offers a workable and self-regulating scheme of umon-employee relations. Because employees would have an unrestricted right to refram from union activity, they could escape umion rules they disagreed with. That right, coupled with the umion's right to expel members at will, would make the internal affairs of a umion self-regulating.

If a member disagreed with his umion's policies and was unable to bring about internal reforins, he could simply refuse to obey the union's demands. The urion, $\mathrm{m}$ turn, could insist that, as a condition of continued inembership, the meniber obey umion rules and perhaps pay a fine or accept sonie other sanction. ${ }^{170}$ If neither the union nor the employee relented, the umion could expel the dissident member. Moreover, should

168. A union breaches its duty of fair representation when it acts in a manner that is "arbitrary, discriminatory, or in bad faith" with respect to a bargaining-unit employee. Vaca v. Sipes, 386 U.S. 171,190 (1967). A union that discriminates against nonmember bargaining unit employees in order to make an example of them or to encourage union membership violates its duty of fair representation. NLRB v. International Longshoremen's Ass'n, 489 F.2d 635, 637-38 (5th Cir.), cert. denied, 419 U.S. 1040 (1974).

169. The Labor-Management Reporting and Disclosure Act of 1959 (LMRDA) specifically regulates several aspects of employee-union relations. Title I of the LMRDA guarantees union members rights aimed at insuring democracy within unions. 29 U.S.C. $\S \S 401-531$ (1982). Protections include due process limitations on union disciplinary procedures, 29 U.S.C. $\$ 411$ (a)(5), freedom to sue the union and its officers if internal procedures are exhausted, 29 U.S.C. $\$ 411$ (a)(4), and certain free speech and assembly rights within the union, 29 U.S.C. $\S 411$ (a)(2). See also Civil Rights Act of 1964, $\S 703$ (c), 42 U.S.C. $\S 2000 \mathrm{e}-2$ (c) (1982) (prohibits union discrimination on the basis of race, color, religion, sex, or national origin).

170. Under this scheme a union's power to discipline members is limited by its power to 
the union attenipt to restrain or coerce him by means other than the threat of expulsion, the employee could seek the protection of the Board.

In deciding whether to disobey a union rule, a member would weigh the advantages of retaining membership against the value of her freedon of action. If expelled, the member would lose the power to influence the bargaining position and policies of her statutory bargaining agent. She would lose the ability to help fix the terms and conditions of her employnient. ${ }^{171}$ She might also lose union unemploynent funds, insurance, and death, nedical, and pension benefits. ${ }^{172}$ But she would keep her job. ${ }^{173}$

In deciding whether to expel a meniber, a union would weigh the advantages of removing a malcontent from its ranks against the need for continued eniployee support. A union that too easily expels menibers risks creating hardened opposition among a faction of bargaining unit employees. Such opposition creates an opportunity for another union to undermine the first union's majority support. Opposition niay also create a rallying point for those who want to decertify a umon. Furthermore, a union would probably lose the right to demand dues fron expelled eniployees, even in an agency shop. ${ }^{174}$

To summarize, a literal approach would provide checks and balances that would niaintain a self-regulating balance of power between umions and eniployees. A umion would be able to nuaintain internal order through its power to expel dissidents. At the sanie time, a nieniber who found union rules oppressive would be free to disobey those rules at no risk to his livelihood. Neitlıer an employee nor a union would make its choices hightly. A union would have to balance the advantages of free-

determine the rules for retention of membership. Thus a union may place any sanction it pleases upon a member, but if the member refuses to acquiesce, the union can only expel the member.

171. Under LMRA § 9(a), 29 U.S.C. § 159(a) (1982), a union is the exelusive bargaining agent for all employees in a bargaining unit, union members and nonunion members alike. If the employce is in a bargaining unit, an employee cannot bargain separately with his employer to set the terms and conditions of his employment. A union is not permitted, however, to arrange for terms and conditions of employment that discriminate between union members and nonunion employees. See supra note 168 and accompanying text.

172. Unpreempted external law governing contracts and voluntary associations may in some instances limit a union's power to withhold reimbursement for employee contributions. Furthermore, a union would breach its duty of fair representation if it were to bargain for benefits and discriminate on the basis of an employee's union activity in distributing those benefits. For example, a union commits an unfair labor practice by withholding benefits it administers when those benefits are a condition of employment. Amalganated Local 286, UAW (Harold Vlasak), 110 N.L.R.B. 371, 376 (1954), enforcement denied, 222 F.2d 95 (7th Cir. 1955).

173. Section 8(a)(3) prevents an employer from discriminating against employees on the basis of union membership or nonmembership, except where an employee is denied membership in an agency shop because he has failed to pay required fees and dues. 29 U.S.C. $§ 158(a)(3)$ (1982).

174. Local 1104, Communications Workers v. NLRB, 520 F.2d 411, 418-19 (2d Cir. 1975) (if union withholds membership for engaging in protected activity, it commits $\S 8(\mathrm{~b})(1)(\mathrm{A})$ and $\S 8(\mathrm{~b})(2)$ unfair labor practices by attempting to collect dues under an agency shop agreement), cert. denied, 423 U.S. 1051 (1976). 
doin froin dissent against its need for continued einployee support. An employee would have to balance the advantages of freedom of action against the costs of being an outcast, unable to influence his bargaining agent's position or to enjoy the economic or social benefits available only through the union.

This scheine would be largely self-administering. There would be no place in it for judicial determinations of the propriety of a particular disciphinary measure. So long as an einployee chose to subinit, a union would be free to take any disciplinary ineasures. Once an employee refused to submit, the union could apply no coercion or restraint beyond depriving the einployee of inembership and its perquisites.

In addition to administrative efficiency, the hiteral approach also would provide clearer rules to guide the conduct of uirions and einployees and to evaluate alleged misconduct. Instead of turning on changing perceptions of the proper balance between institutional and individual interests, the rights of uinons and einployees would be permanently fixed. A uinon would be free to impose any restraints on its ineinbers, but these would be enforceable only by the union's power to withhold ineinbership. An eniployee or his employer would know that any union restraint or coercion restricting the employee's free exercise of his section 7 rights is an unfair labor practice that the Board will halt.

By providing clear rules and minimizing the necessity for outside intervention, the hteral approach advocated here wonld be less susceptible to changes in the pohtical, ideological, or philosophical biases of Board inenibers and judges. In contrast, the present balancing of legitimate union interests and federal labor policy in effect places no principled restrictions upon an administrative law judge's, Board nneinber's, or judge's free exercise of discretion, beyond the vague and shifting guidance of precedent in this area.

Finally, the approach advocated here is true to the language of the Taft-Hartley amendnients. It effectively insnlates an eniployee's organizational activity or inactivity from his job, yet respects a union's freedom to order its internal affairs through control of its inenibership policies.

\section{CONCLUSION}

Literally apphied, sections 7 and $8(\mathrm{~b})(1)(\mathrm{A})$ would provide a fair, self-regulating schente for permitting unions to control their internal affairs while effectively insulatimg an einployee's organizational activity, or lack thereof, froin union restraint or coercion. The courts and the Board followed just this approach for twenty years. When they wandered from literal application of the statute, however, the courts and the Board created the "disinal swamp of uncertainty" predicted by an 
early commentator. ${ }^{175}$ Furthermore, by tizying to balance the apparent equities of presented cases, they have limited unions' power to remove dissident members, significantly undermining unions' institutional intcgrity. A return to a literal approach would permit unions to remove disobedient members from their ranks so that the union could maintain an effective, uniform position from which to apply bargaining pressure upon employers. Literal application of the statute would also permit any bargaining unit employee to abstain from collective activity without risking her livelihood.

Kevin C. Marcoux*

175. Cox, supra note 8 , at 33 .

* B.A. 1981, University of California, Santa Cruz; J.D. 1986, Boalt Hall School of Law, University of California, Berkeley. 